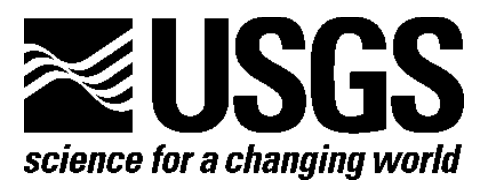

\title{
An Examination of Selected Historical Rainfall-Induced Debris-Flow Events within the Central and Southern Appalachian Mountains of the Eastern United States
}

By G.F. Wieczorek, L.S. Eaton, B.A. Morgan, R.M. Wooten, and M. Morrissey

Report Series 2009-1155

U.S. Department of the Interior

U.S. Geological Survey 


\section{U.S. Department of the Interior \\ KEN SALAZAR, Secretary}

\section{U.S. Geological Survey \\ Suzette M. Kimball, Acting Director}

U.S. Geological Survey, Reston, Virginia 2009

For product and ordering information:

World Wide Web: http://www.usgs.gov/pubprod

Telephone: 1-888-ASK-USGS

For more information on the USGS-the Federal source for science about the Earth,

its natural and living resources, natural hazards, and the environment:

World Wide Web: http://www.usgs.gov

Telephone: 1-888-ASK-USGS

Suggested citation:

Wieczorek, G.F., Eaton, L.S., Morgan, B.A., Wooten, R.M., and Morrissey, M., 2009, An examination of selected historical rainfall-induced debris-flow events within the central and southern Appalachian Mountains of the Eastern United States: U.S. Geological Survey Open-File Report 2009-1155, 25 p.

Any use of trade, product, or firm names is for descriptive purposes only and does not imply endorsement by the U.S. Government.

Although this report is in the public domain, permission must be secured from the individual copyright owners to reproduce any copyrighted material contained within this report. 


\section{Contents}

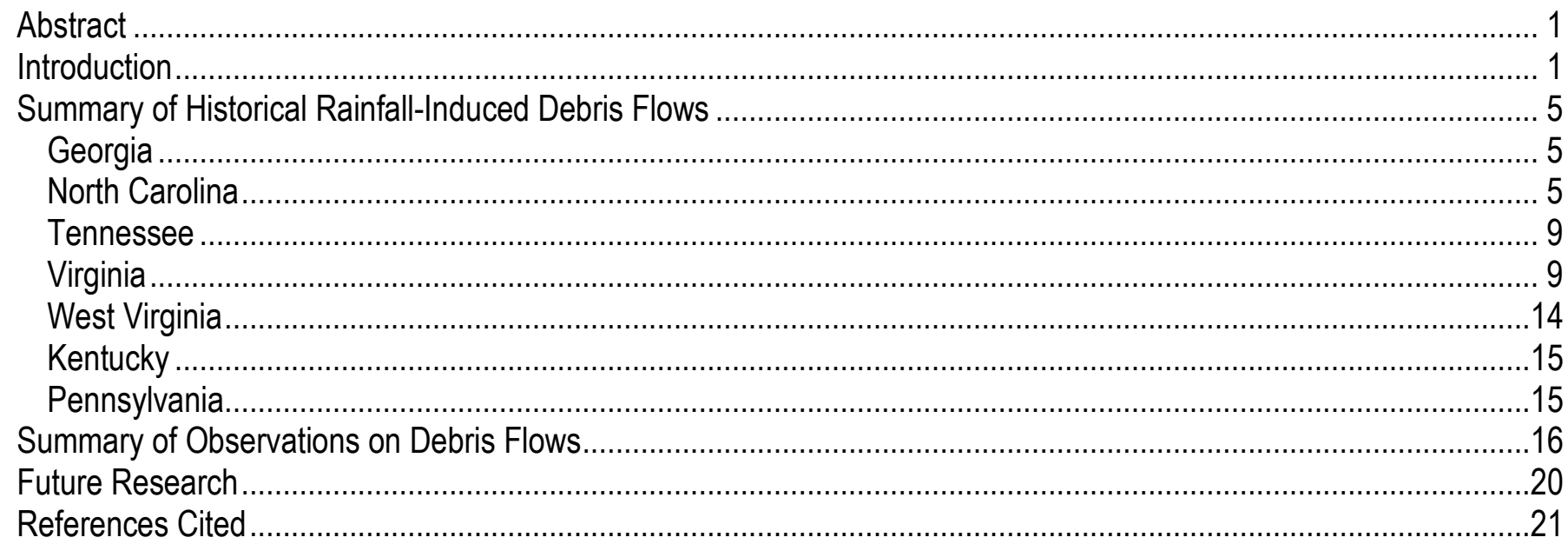

\section{Figures}

1. Distribution of debris flows within the Appalachian Mountains of the Eastern United States...

2. Map showing locations of slope movements triggered by rainfall from Hurricanes Frances and Ivan September 7-17, 2004, in the western North Carolina region .............................................................. 7

3. Photographs of results of landslide and debris flow that occurred on September 16, 2004, in Macon County, N.C.

4. Isohyetal map of rainfall resulting from Hurricane Camille in the Lovingston and Horseshoe Mountain 7.5 minute quadrangles Nelson County, Va. ..................................................................................10

5. Photographs of debris flow and damage to a home in Madison County during storm of June 27, 1995.........12

6. Scour from June 27, 1995, debris flow in Madison County revealing older debris-flow deposits....................13

7. $\quad$ Graph showing rainfall intensity and duration for storms in the Blue Ridge of central Virginia ........................17

8. Graph showing rainfall and a few observed times of debris flows during the June 27, 1995, storm in Madison County, Va.

9. Graph showing rainfall intensity-duration for debris-flow thresholds for Blue Ridge; Hawaii, San Francisco Bay region, and Puerto Rico

\section{Table}

1. Examples of historical rainfall-induced landslides within Appalachian Mountains of the Eastern United States 


\section{Conversion Factors}

\begin{tabular}{lcl}
\hline \multicolumn{1}{c}{ Multiply } & By & \multicolumn{1}{c}{ To obtain } \\
\hline millimeter $(\mathrm{mm})$ & Length & \\
meter $(\mathrm{m})$ & 0.03937 & inch (in.) \\
kilometer $(\mathrm{km})$ & 3.281 & foot $(\mathrm{ft})$ \\
\hline & 0.6214 & mile (mi) \\
\hline square meter $\left(\mathrm{m}^{2}\right)$ & Area & \\
square kilometer $\left(\mathrm{km}^{2}\right)$ & 0.0002471 & acre \\
\hline & 0.3861 & square mile $\left(\mathrm{mi}^{2}\right)$ \\
\hline cubic meter $\left(\mathrm{m}^{3}\right)$ & Volume & \\
\hline & 264.2 & gallon $(\mathrm{gal})$ \\
\hline meter per second $(\mathrm{m} / \mathrm{s})$ & Flow rate & \\
meter per hour $(\mathrm{m} / \mathrm{hr})$ & 3.281 & foot per second $(\mathrm{ft} / \mathrm{s})$ \\
& 3.281 & foot per hour $(\mathrm{ft} / \mathrm{hr})$ \\
\hline
\end{tabular}




\title{
An Examination of Selected Historical Rainfall- Induced Debris-Flow Events within the Central and Southern Appalachian Mountains of the Eastern United States
}

By G.F. Wieczorek, L.S. Eaton, B.A. Morgan, R.M. Wooten, and M. Morrissey

\begin{abstract}
Generally, every several years, heavy amounts of rainfall trigger a large number of debris flows within the central and southern Appalachian Mountains of the Eastern United States. These types of landslides damage buildings, disrupt infrastructure, and occasionally injure and kill people. One of the first large debris flows was described in Pennsylvania in August 1779. The most destructive event occurred during August 19-20, 1969, in Nelson County, Va. During a period of 8 hours, 710 to 800 milimeters of rain triggered more than 3,000 landslides, killing more than 150 people. As the population increases in this region, future storms will likely increase the risks of property damage and loss of life. We provide a general overview of debris flows in the Appalachians, using a compilation of 19 storm events for which rainfall, duration of the storm, and descriptions of the resulting landslides have been substantially documented.
\end{abstract}

\section{Introduction}

Landslides, including debris flows, have occurred throughout mountainous areas of the United States, triggered by rainfall, earthquakes, or volcanoes. The steep slopes and poor slope stability associated with regions of the Colorado Plateau, the Appalachian Highlands, the Coast Ranges of California, and the Southern Rocky Mountains produce the greatest concentration of landslide prone areas and a variety of landslides (RadbruchHall and others, 1982; Wieczorek and Leahy, 2008). In the Appalachian region, landslides result primarily from heavy rainfall. Rainfall from hurricanes, cloudbursts, and thunderstorms can generate rapidly moving debris flows that are among the most dangerous and damaging type of landslides. In this publication, we explore the nature and occurrence of debris flows in the central and southern Appalachian Mountains, which extend from central Pennsylvania to Georgia.

A debris flow is a moving mass of fragmented rock and soil in which more than half of the particles are greater than sand size (Costa, 1988). Because a debris flow moves rapidly and with great force, it is capable of destroying almost everything in its path. Debris flows are most frequently generated on steep slopes during heavy rainfall and often travel along preexisting drainages and streams. The soils and poorly consolidated material on these slopes may become saturated during rainfall, lose coherence, and begin 
moving downslope in a flowing stream, drawing in and transporting additional soil, rocks, and vegetation as the flow rapidly moves through the drainage network (Campbell, 1975).

The first debris flow described in the Appalachian region occurred in 1779, about $16 \mathrm{~km}$ northwest of Carlisle, Pa. The event was observed by David Rittenhouse in a letter he was writing to Benjamin Franklin (Delano and Potter, 1997; Potter and Delano, 1997). Ground failure resulted in a debris flow that mobilized rocks and trees that were carried downslope about 800 meters $(\mathrm{m})$ in a channel 1 to $4 \mathrm{~m}$ deep and 9 to $30 \mathrm{~m}$ wide.

A valuable summary of debris-flow events within the Appalachians south of the glacial border was compiled by Clark (1987a). He provided a bibliography and a location map of 51 debris-flow events resulting from rainstorms that occurred between 1844 and 1985. More recently, several large-scale, storm-induced debris-flow events that occurred since 1987 have been documented in this region by Jacobson (1993), Morgan and Wieczorek (1996), Morgan and others (1999), Wieczorek and others (2000), and Wooten and others (2008a, b). Many debris-flow events have occurred in isolated areas with few inhabitants, so that valuable information on affected slopes, number of ground failures, rainfall, and duration of rainfall is lacking. We have compiled data in table 1 for 19 events within this region for which we have substantial information. The geographic locations of these data, combined with findings from Clark (1987a), are plotted on figure 1; the debris flows listed in table 1 are shown as small asterisks and are numbered. 


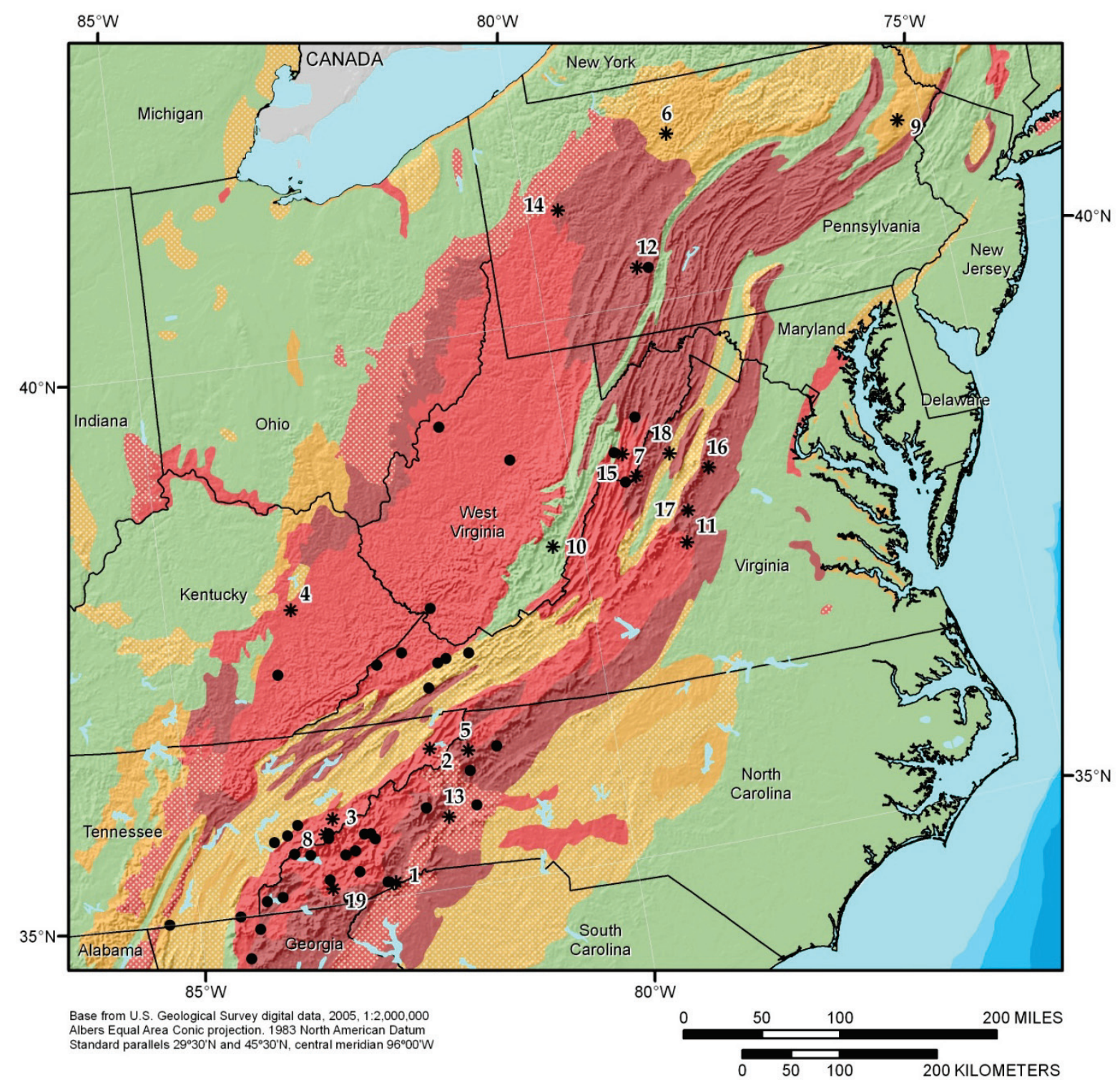

\section{EXPLANATION}

- Historical landslide event

* 11 Event listed on table 1.

Low debris flow incidence (less than 1.5 percent of area)

Moderate debris flow incidence (1.5 - 15 percent of area)

High debris flow incidence (more than 15 percent of area)

Moderate debris flow susceptibility

High debris flow susceptibility

High debris flow incidence and susceptibility

Figure 1. Distribution of debris flows within the Appalachian Mountains of the Eastern United States (Clark, 1987a; Radbruch-Hall and others, 1982). 
Table 1. Examples of historical rainfall-induced landslides within Appalachian Mountains of the Eastern United States.

\begin{tabular}{|c|c|c|c|c|c|c|}
\hline $\begin{array}{l}\text { Map } \\
\text { location } \\
\text { of debris } \\
\text { flows on } \\
\text { figure } 1\end{array}$ & $\begin{array}{c}\text { Rainfall } \\
\text { total } \\
\text { (milimeters) }\end{array}$ & $\begin{array}{l}\text { Time of } \\
\text { most severe } \\
\text { rainfall }\end{array}$ & Type of rainfall storm & $\begin{array}{l}\text { Number of } \\
\text { reported } \\
\text { landslides }\end{array}$ & $\begin{array}{c}\text { Landslide } \\
\text { dates } \\
\text { (month/day/year) }\end{array}$ & General landslide locations \\
\hline 1 & 564 & $24 \mathrm{hrs}$ & Hurricane & 45 & $7 / 15-16 / 1916$ & $\begin{array}{l}\text { Transylvania County, North Carolina (Wooten and others, } \\
\text { 2003) }\end{array}$ \\
\hline 2 & 380 & 2 days & Thunderstorm & $\sim 100$ & $6 / 13 / 1924$ & Carter County, Tennessee (Scott, 1972) \\
\hline 3 & 305 & $4 \mathrm{hrs}$ & Cloudburst & $>100$ & $8 / 45 / 1938$ & Webb Mountain, Tennessee (Scott, 1972) \\
\hline 4 & 508 & 2 days & Thunderstorm & $\begin{array}{l}4 \text { on photo, but } \\
\text { total not reported }\end{array}$ & $7 / 4-5 / 1939$ & $\begin{array}{l}\text { Wolfe and Breathitt County, eastern Kentucky (Schrader, } \\
\text { 1945) }\end{array}$ \\
\hline 5 & 254 & $6 \mathrm{hrs}$ & Hurricane & 2,099 & $8 / 10-17 / 1940$ & Watauga County, North Carolina (Wooten, 2008a) \\
\hline 6 & 782 & $4.5 \mathrm{hrs}$ & Thunderstorm & numerous & $7 / 18 / 1942$ & $\begin{array}{l}\text { Elk, McKean, Potter, \& Cameron Counties, north-central } \\
\text { Pennsylvania (Scott, 1972) }\end{array}$ \\
\hline 7 & 400 & 1 day & Cloudburst & 466 & $6 / 1718 / 1949$ & $\begin{array}{l}\text { Augusta \& Rockingham Counties, Virginia/Highland County, } \\
\text { West Virginia (Hack and Goodlett, 1960) }\end{array}$ \\
\hline 8 & 116 & $1 \mathrm{hr}$ & Cloudburst & 100 & $9 / 1 / 1951$ & $\begin{array}{l}\text { Mt. Le Conte, Great Smoky Mountains National Park, } \\
\text { Tennessee (Scott, 1972) }\end{array}$ \\
\hline 9 & 254 & 2 days & Hurricane Diane & 4 & $8 / 18-19 / 1955$ & Brodhead Creek, northeastern Pennsylvania (Scott, 1972) \\
\hline 10 & 635 & $8 \mathrm{hrs}$ & Hurricane Camille & 1,584 & $\begin{array}{r}8 / 19-20 / 1969 \\
9 / 5-6 / 1969\end{array}$ & $\begin{array}{l}\text { Spring Creek, Greenbrier County, West Virginia (Schneider, } \\
\text { 1973) }\end{array}$ \\
\hline 11 & $710-800$ & $8 \mathrm{hrs}$ & Hurricane Camille & 3,793 & $8 / 19-20 / 1969$ & Nelson County, Virginia (Willams and Guy, 1973) \\
\hline 12 & 300 & 9 hrs & $\begin{array}{l}\text { Thunderstorm or } \\
\text { cloudburst }\end{array}$ & Several hundred & $7 / 19-20 / 1977$ & Johnstown area, western Pennsylvania (Pomeroy, 1980) \\
\hline 13 & 320 & 5 days & Storm & 72 & $11 / 6-7 / 1977$ & Buncombe County, North Carolina (Neary and Swift, 1987) \\
\hline 14 & 115 & 14 days & Thunderstorm & 62 & $8 / 14 / 1980$ & $\begin{array}{l}\text { East Brady, along Allegheny River, northern Pennsylvania } \\
\text { (Pomeroy, 1984) }\end{array}$ \\
\hline 15 & 350 & 3 days & Hurricane Juan & 3,000 & $11 / 3-5 / 1985$ & $\begin{array}{l}\text { Pendleton County, West Virginia/Highland County, Virginia } \\
\text { (Jacobson and others, 1993) }\end{array}$ \\
\hline 16 & 770 & $14 \mathrm{hrs}$ & Storm & 629 & $6 / 27 / 1995$ & Madison County, Virginia (Wieczorek and others, 2000) \\
\hline 17 & 635 & 1 day & Storm & 61 & $6 / 27 / 1995$ & Albemarle County, Virginia (Morgan and Wieczorek, 1996) \\
\hline 18 & 513 & 1 day & Hurricane Isabel & 6 & $9 / 18-19 / 2003$ & Shenandoah Valley, Virginia (Wieczorek and others, 2004) \\
\hline 19 & 700 & 11 days & $\begin{array}{l}\text { Hurricanes Frances } \\
\text { and Ivan }\end{array}$ & 400 & $9 / 7-17 / 2004$ & Western North Carolina (Wooten and others, 2008a) \\
\hline
\end{tabular}




\section{Summary of Historical Rainfall-Induced Debris Flows}

We will describe the 19 debris-flow events listed and located in table 1 and figure 1 , respectively, as well as other less well-documented flows, by each of the several States in the region. These descriptions will provide the basis for a summary of the general conditions that cause these devastating landslides. We will conclude with a discussion of research that could increase the ability of Federal and State agencies to predict and mitigate the risk posed by debris flows.

\section{Georgia}

The latter half of the month of August 1967 was excessively rainy throughout the north Georgia mountains (Scott, 1972). During most of the period, a stationary front was just to the north of the area, producing highly unstable atmospheric conditions, with periods of steady rain, as well as numerous heavy showers and thunderstorms. Small groups of debris slides and flows occurred at several widely separated sites in apparent response to local concentrations of exceptionally heavy precipitation. The primary rainfall center appears to have been located about 13 to 14 kilometers $(\mathrm{km})$ south of the town of Blue Ridge, where an estimated 305 to 381 milimeters $(\mathrm{mm})$ or more of rain fell during the period of August 19-27. Here, within an area of a few square kilometers, approximately 10 debris flows occurred on undisturbed slopes located largely within the Chattahoochee National Forest. The three largest slides had multiple sources or heads, and considerable bedrock was exposed along their paths. The largest of these slides was over $900 \mathrm{~m}$ long and was initiated at three sources.

On the evening of August 17, 1982, a low pressure system stagnated over northwest Georgia and southeast Tennessee and produced an excessive amount of rainfall (Wilson, 1983). Two hundred-fifty to three hundred mm of rain fell in a 12-hour period in parts of Dade County in Georgia, and Marin and Hamilton Counties in Tennessee. Debris flows were triggered along the steep (greater than 30 degrees) slopes of the Cumberland Plateau Escarpment in an area of about 84 square kilometers $\left(\mathrm{km}^{2}\right)$. These debris flows were triggered within 8 to 10 hours from the onset of the rainfall. Most of the flows began as translational slides within colluvium overlying a variety of bedrock types. The thickness of the colluvium contributed to the initial failure site, and the interface between the bedrock and the soil formed the basal failure surface. The ensuing flash floods and landslides caused over 8 million dollars in property damage and resulted in 4 deaths (Wilson, 1983).

\section{North Carolina}

In early July, 1916, a storm passed over western North Carolina, producing nearly $250 \mathrm{~mm}$ of rain but no recorded slope movements. Shortly afterwards during July 15-16, a hurricane struck the counties of Transylvania, Henderson, and Buncombe, greatly affecting the towns of Brevard, Hendersonville, and Asheville. Heavy rains associated with this second storm caused much flooding and damage from slope movements that probably numbered at least in the hundreds, if not thousands, over a large area affecting five States (Wooten and others, 2003). The Tennessee Valley Authority (TVA, 1964) recorded $564 \mathrm{~mm}$ of rainfall in 24 hours near Altapass, N.C., during the storm. Residents reported over 45 landslides on the mountain sides around Brevard, N.C. (Wooten and others, 2003). At least three people were killed near Brevard as a direct result of these debris flows.

During the month of August 1940, the southeastern United States experienced two major hurricanes that caused damages of about $\$ 30$ million. The first and larger of these two storms occurred during the week of August 10-17, 1940, and the southeastern States of Georgia, Tennessee, North Carolina, and Virginia experienced severe damage. The track of the storm was highly erratic, coming 
ashore near Savannah, Ga., passing through Atlanta, then swinging in a broad arc west of Knoxville, Tenn., and finally easterly across North Carolina and southern Virginia. The center of the storm, with intense rainfall, passed between the cities of Boone and Wilkesboro, N.C., between 6:00 a.m. and 12:00 noon on August 14. This event dropped a maximum of $254 \mathrm{~mm}$ of rain within 6 hours at Laurel Springs, N.C., and had been preceded by $86 \mathrm{~mm}$ of rain on August 13. In western North Carolina, flooding in many rivers was at an historical maximum. In this area, 26 people were reportedly killed, including 1 from a debris flow. Of these, nine were killed in the Stony Fork Township near Deep Gap in eastern Watauga County (Witt and others, 2007). One of the most significant features associated with this storm was the large number of shallow debris flows that traveled down steep, forested slopes into small valleys along the Blue Ridge. The source of these flows was from thin, saturated soils overlying bedrock on steep slopes. According to field observations, the size of debris flows varied from about $2 \mathrm{~m}$ wide and from 12 to $15 \mathrm{~m}$ long, to 60 to $90 \mathrm{~m}$ wide and 400 to $800 \mathrm{~m}$ long, with a maximum track length of 2,097 m measured from aerial photography flown in 1940 (Witt and others, 2008). Many of the larger debris flows continued down the slopes into the stream valleys removing trees and structures in their path. Over 2,000 debris flows and debris slides occurred (Wooten and others, 2008b) of which 763 debris flows were in the Deep Gap area of Watauga County (Wieczorek and others, 2004).

A second storm struck southwestern North Carolina during August 28-31, 1940, with the heaviest rainfall of 241-305 $\mathrm{mm}$ reported over a 24-hour period in the headwaters of the Tuckasgee River in Jackson County (TVA, 1940; U.S. Geological Survey, 1949). Because of the concentration of high-intensity rainfall within a small area, more than 200 debris flows occurred in an area of only 388 $\mathrm{km}^{2}$ (U.S. Geological Survey, 1949). Debris slides and flows triggered by this storm claimed six lives in the Tuckasegee River and upper Pigeon river areas of Jackson and Haywood Counties (TVA, 1940).

During November 3-7, 1977, a storm produced intense and heavy rainfall triggering debris flows on the steep slopes of the Pisgah National Forest, N.C. Total precipitation in the Asheville area ranged from 53 to $320 \mathrm{~mm}$ (Neary and Swift, 1987). There were at least 72 major debris flows that occurred near the end of the storm in the Bent Creek area of Buncombe County (Pomeroy, 1991). The debris flows generally ranged from 655 to $810 \mathrm{~m}$ long, with the largest maximum runout of at least $1,235 \mathrm{~m}$ (Neary and Swift, 1987).

During 2004, Hurricane Frances (September 7-8) and Hurricane Ivan (September 16-17) swept through western North Carolina. Precipitation in Macon County from Hurricane Frances at Mooney Gap (elevation $1,364 \mathrm{~m}$ ) totaled approximately $205 \mathrm{~mm}$ and at Coweeta (elevation $685 \mathrm{~m}$ ) totaled approximately $118 \mathrm{~mm}$ (Wooten and others, 2008a). Hurricane Ivan produced precipitation totals in Macon County ranging from 100 to $125 \mathrm{~mm}$ in the north to 250 to $300 \mathrm{~mm}$ in the south. Mooney Gap received an additional approximately $204 \mathrm{~mm}$ of precipitation, and another $114 \mathrm{~mm}$ of rain fell at Coweeta. Short-duration rainfall rates of 90-230 milimeters per hour $(\mathrm{mm} / \mathrm{hr})$ were measured during this period, and an average rainfall rate and duration of $25 \mathrm{~mm} / \mathrm{hr}$ for 4.65 hours occurred just prior to two debris flows where the initiation times were known (Wooten and others, 2008a). At least 400 ground failures, including debris flows, resulted from these storms in North Carolina (R.M. Wooten, written commun., 2009), and a few additional landslides were also reported in Tennessee, West Virginia, Ohio, and Pennsylvania. The Peeks Creek debris flow began at an elevation of $1,347 \mathrm{~m}$ on the northeast side of Fishhawk Mountain, probably as a debris slide, measuring approximately $23 \mathrm{~m}$ wide, $100 \mathrm{~m}$ long, and about $1 \mathrm{~m}$ thick. This slide translated into a debris flow and traveled $3.6 \mathrm{~km}$ downslope to the Cullasaja River, killing 5 people, injuring 2 seriously, and destroying 16 houses, making this the most devastating of all landslides during the September 2004 storms. Calculated estimates of peak velocity [14.8 meters per second $(\mathrm{m} / \mathrm{s})]$ and discharge $\left[\left(1,275\right.\right.$ to 1,980 cubic meters $\left.\left(\mathrm{m}^{3}\right)\right]$ explain why this debris flow was so destructive (Latham and others, 2005, 2006). Figure 2 shows the known 
locations of slope movements triggered by rainfall from Hurricanes Frances and Ivan on September 7 to 17 in the western North Carolina region (Latham and others, 2007). Detailed observations of rock slides were made at several specific times (R.M. Wooten, written commun., 2008). For example, during September 6-8, one slide of fresh rock and two slides of weathered rock occurred during rainfall from the remnants of Hurricane Frances; during September 6-17, one slide of weathered rock was triggered from rainfall from the remnants of Hurricane Frances or Ivan. During September 16-17, one rock slide, two slides of weathered rock, one composite debris rockslide, and one rock fall were triggered by rain from remnants of Hurricane Ivan. Residents in the Peeks Creek community reported that a debris flow occurred during Hurricane Ivan on September 16, 2004 (fig. 3).

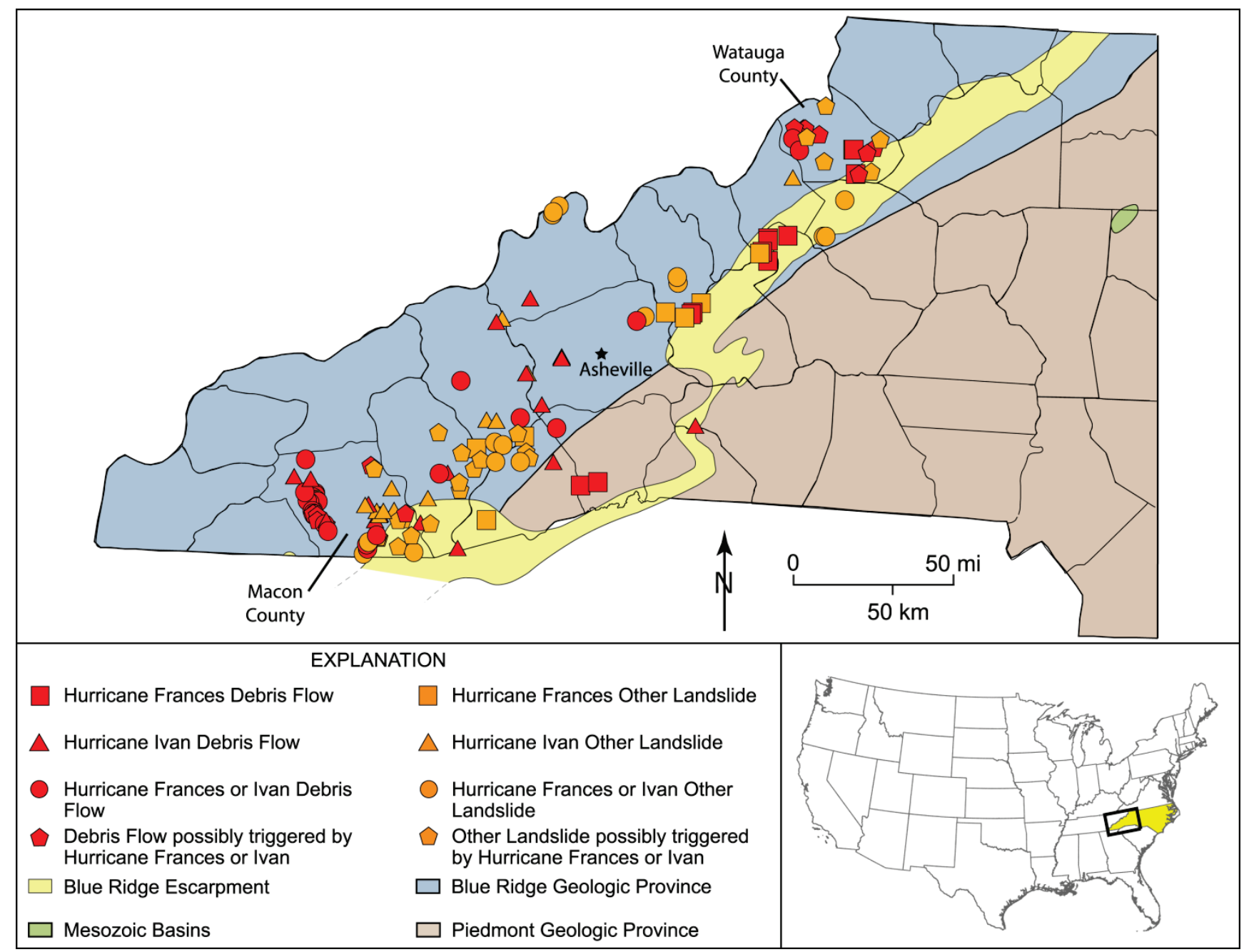

Figure 2. Map showing locations of slope movements triggered by rainfall from Hurricanes Frances and Ivan September 7-17, 2004, in the western North Carolina region (Latham and others, 2007). 

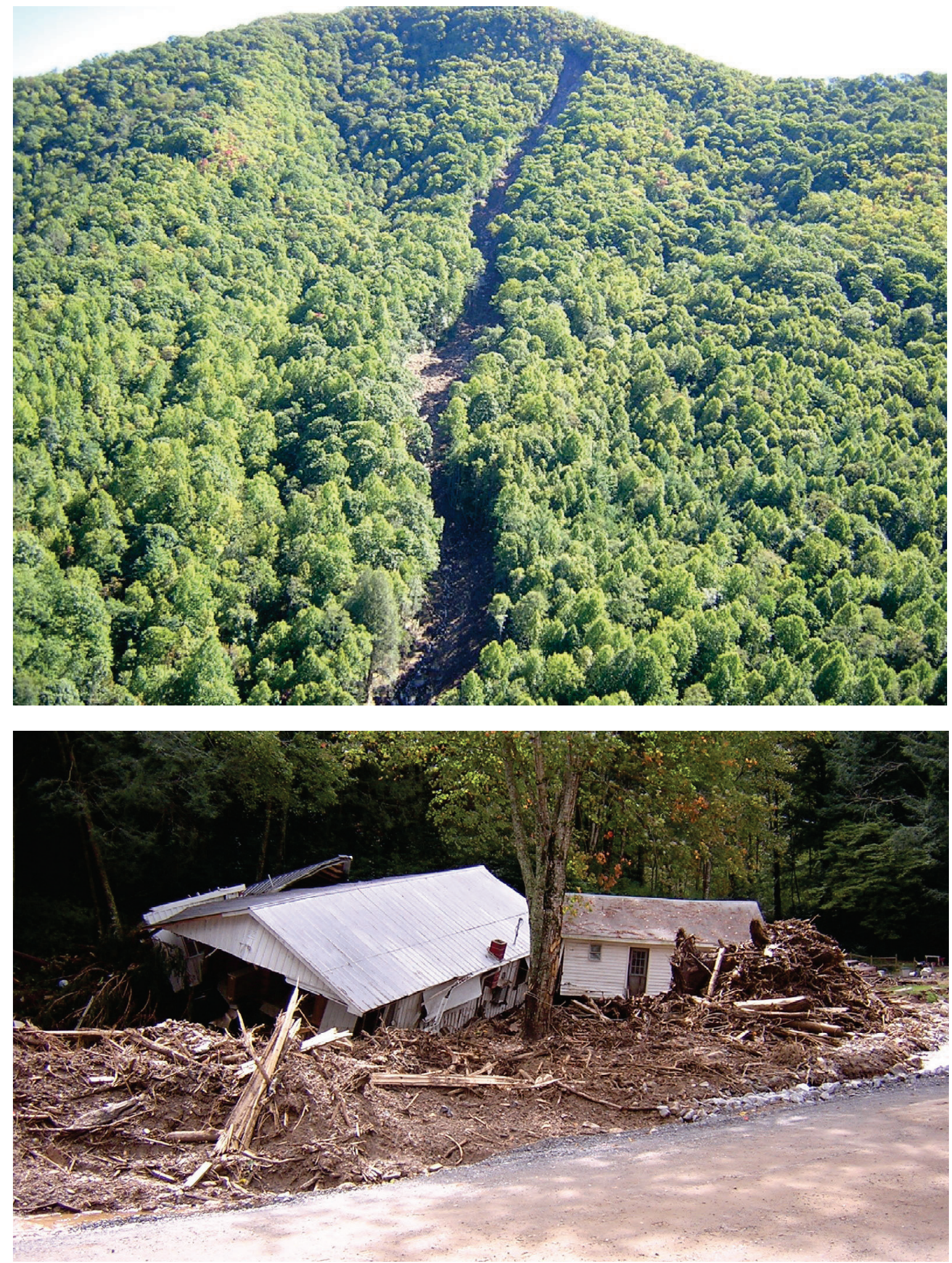

Figure 3. A. Peaks Creek landslide and debris flow in Macon County, N.C., that occurred on September 16, 2004. B. Buildings destroyed by the debris flow at Peaks Creek, September 16, 2004. (Photos by R.M. Wooten, N.C. Geological Survey). 


\section{Tennessee}

On June 13, 1924, in Carter County, eastern Tenn., a thunderstorm brought $380 \mathrm{~mm}$ of rainfall within 2 days and triggered approximately 100 landslides. Near the center of the storm, a substantial number of these failures were debris slides and flows. At least 11 people were killed by the storm and its accompanying slope failures. At Carden's Bluff, two small houses were demolished and nine occupants killed (Scott, 1972).

During August 4-5, 1938, a severe storm produced $305 \mathrm{~mm}$ of rain within 4 hours, resulting in about 100 landslides, including debris flows. Within the Great Smoky Mountains National Park, the areas of severe rainfall extended from the general vicinity of Calderwood, located on the Little Tennessee River, northeastward to near Cosby, on the Pigeon River, a distance of approximately $80 \mathrm{~km}$ (Scott, 1972). Along the Little Tennessee River, there were numerous small landslides, and at least one modern bridge near Calderwood Dam was destroyed, as well as many small bridges and buildings (Koch, 1974).

A cloudburst on September 1, 1951, in the Mount Le Conte-Sugarland Mountain area of the Great Smoky Mountains National Park resulted in numerous debris flows and related flood damage (Bogucki, 1976). The affected area is predominantly steep and is covered with virgin forest. Slide-head elevations range from 1,280 to 1,920 $\mathrm{m}$ (Scott, 1972). Slide-head slopes have a mean of 40 degrees, with a range of 35 to 44 degrees, with an average of 38 degrees (Bogucki, 1976). Sixty-three percent of the known slides occur on slate of the Anakeesta Formation and 37 percent on metasandstone. The largest slide in the Alum Cave Creek watershed (Slide SB-10) has a slope area of 10,500 $\mathrm{m}^{2}$, with an estimated regolith removal of $3,400 \mathrm{~m}^{3}$ (Bogucki, 1976).

\section{Virginia}

In August 1969, Hurricane Camille made landfall with great destruction on the Gulf Coast and moved inland in a large north-to-northeastern arc into the Appalachian region of West Virginia and Virginia. In the area around Nelson County, Va., the eastward movement of the remnants of the hurricane stalled against a high pressure system, resulting in at least $710 \mathrm{~m}$ of rainfall during an 8-hour period during the night of August 19-20 (Williams and Guy, 1973). The U.S. Weather Bureau, after conducting bucket surveys, confirmed $800 \mathrm{~mm}$ of rainfall at one point and 635 to $686 \mathrm{~mm}$ in several other places (Simpson and Simpson, 1970). A careful review of the available rainfall data was conducted by Morgan and others (1999) resulted in an isohyetal map of rainfall in the central area of the storm that is consistent with the known data (fig. 4). The affected bedrock was metagranite and granitic gneiss. More than 3,793 debris flows occurred in the Nelson County area, identified by aerial photography taken immediately after the storm (Morgan and others, 1999). The heavy rain fell during the night, which contributed to the estimated 150 deaths from debris flows and flooding. Small road bank slides began occurring as early as 10:00 p.m., and, according to one resident, large debris flows began by 11:00 p.m. in Polly Wright Cove, a few miles north of Lovingston. By 1:00 a.m., the debris flows were occurring in large numbers and continued to do so until about 4:00 a.m. The ground failures usually began at an elevation of about $550 \mathrm{~m}$ on slopes averaging 32 degrees. The average of many debris flows was $775 \mathrm{~m}$ long and $14 \mathrm{~m}$ wide (Scott, 1972). 


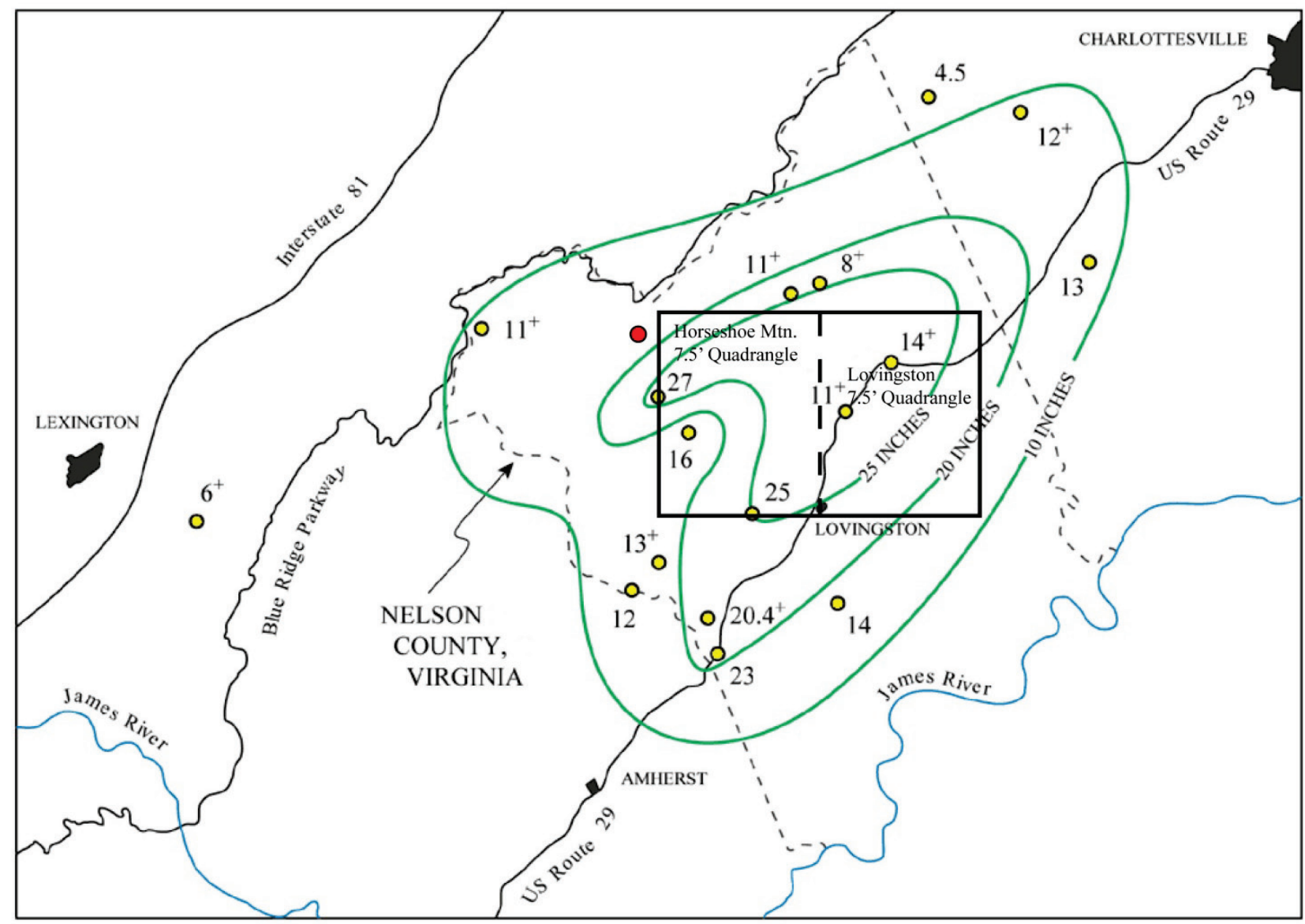

Figure 4. Isohyetal map of rainfall resulting from Hurricane Camille, August 1969, in the Lovingston and Horseshoe Mountain 7.5 minute quadrangles Nelson County, Va. (Morgan and others, 1999). Rainfall data marked with a "+" sign indicates rain gages that overflowed; they represent values that are necessary but not sufficient to determine the isohyetal contours (scale 1:500,000).

Nearly 30 years later, as much as $770 \mathrm{~mm}$ of rain fell in a restricted area near Graves Mill, Madison County, Va., between 10 a.m. to 1 p.m. on June 27, 1995. Antecedent rainfall during the 5 days preceding the major June 27 storm ranged from 75 to $170 \mathrm{~mm}$, increasing the moisture content in thin regolith and weathered bedrock. The storm was tracked by the U.S. Weather Service and a detailed analysis was published by Smith and others (1996). Bucket surveys of rainfall data enabled researchers to develop isohyets (lines of equal precipitation), and extensive interviews of residents in the area provided valuable information on the timing of debris flows and rainfall totals that could then be correlated with the location of the storm and the rate of rainfall at the time of the debris flow (Wieczorek and others, 2000). A detailed map of the debris flows and flooding was compiled based on infrared aerial photography taken 6 weeks after the storm (Morgan and others, 1999a). This map also included isohyets and the track and timing of the storm. At least 629 debris flows were mapped within a relatively small area of $130 \mathrm{~km}^{2}$. The debris flows were generated on slopes averaging $30 \pm 3.7$ degrees and an elevation of approximately $350 \mathrm{~m}$. Debris slides were generated in weathered granitic and gneissic rock. Downslope, these usually became fluid within a few tens of meters and entrained as much as 90 percent of their final volume during their descent to the fans and flood plains of the Rapidan, 
Robinson, and Conway Rivers. In the area of Graves Mill, a number of farms, as well as roads and bridges, were severely damaged (fig. 5). During this event, older debris fans were extensively incised to reveal a complex stratigraphy of debris-flow deposits interbedded with slope-wash colluvium and minor alluvium. All of the larger debris-flow deposits that were incised were found to have a composited stratigraphy, giving evidence of a history of multiple events. Figure 6 is a photograph showing scour from the July 1995 storm with lag deposits of fresh boulders from the 1995 debris flow in the bottom of the channel. Slope wash colluvium overlies at least two deeply weathered debris flows of Pleistocene age. Sufficient charcoal was obtained from similar deposits and carbon $14\left(\mathrm{C}^{14}\right)$ dates provide evidence that the area has been affected by debris flows from more than 50,000 years before present (ybp) (the limit of $\mathrm{C}^{14}$ determinations) to the present, with the majority of dated deposits ranging from 26,000 to 13,000 ybp (Eaton and McGeehin, 1997; Eaton, 1999; Eaton and others, 2003a). The period of intense rainfall occurred during the morning and early afternoon, and county officials were able to warn many residents of these dangerous conditions. Only one person died.

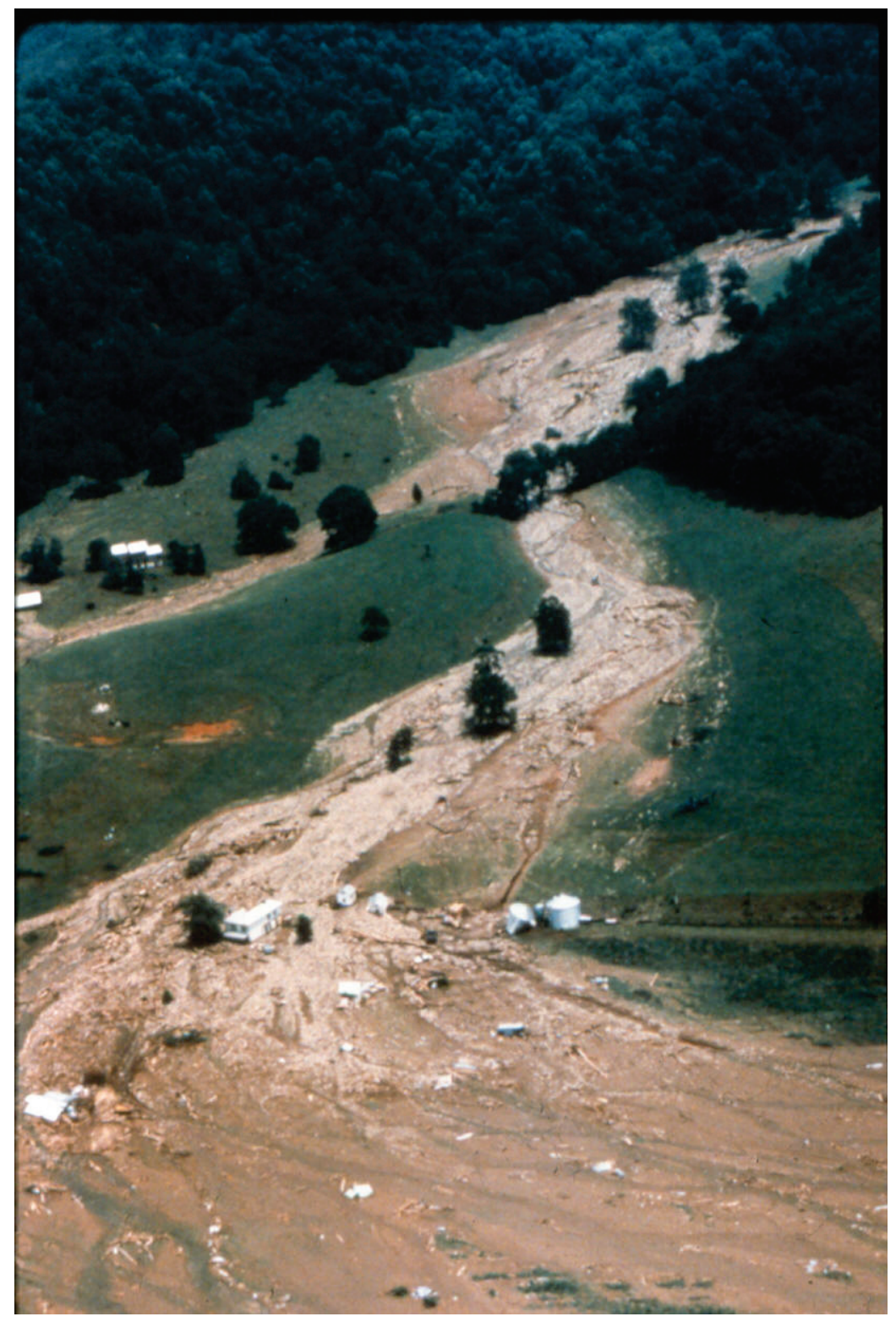




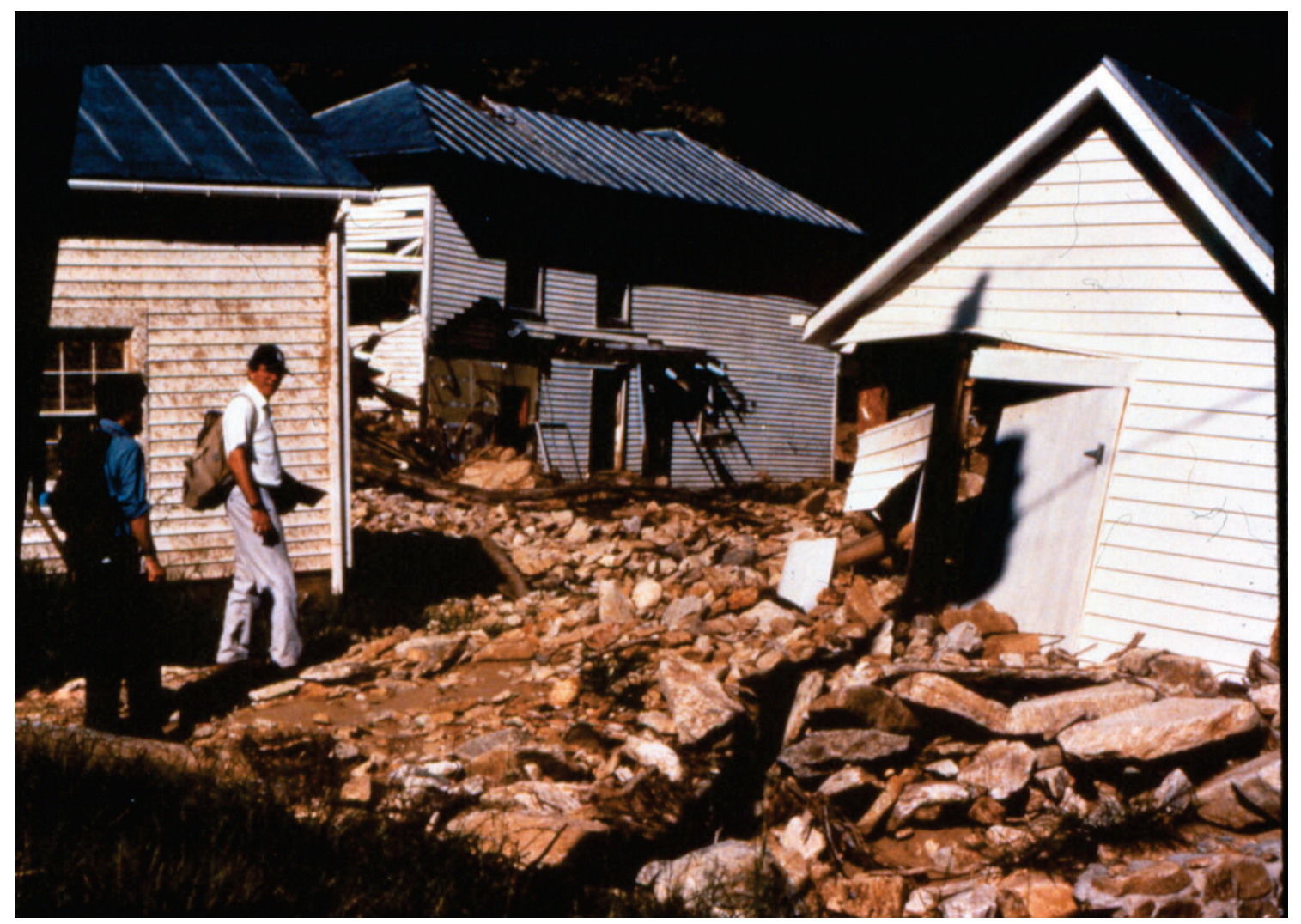

Figure 5. A. Debris flow that destroyed a home in Madison County during storm of June 27, 1995. B. Damage to the home. (Photo taken August 18, 1995.) 


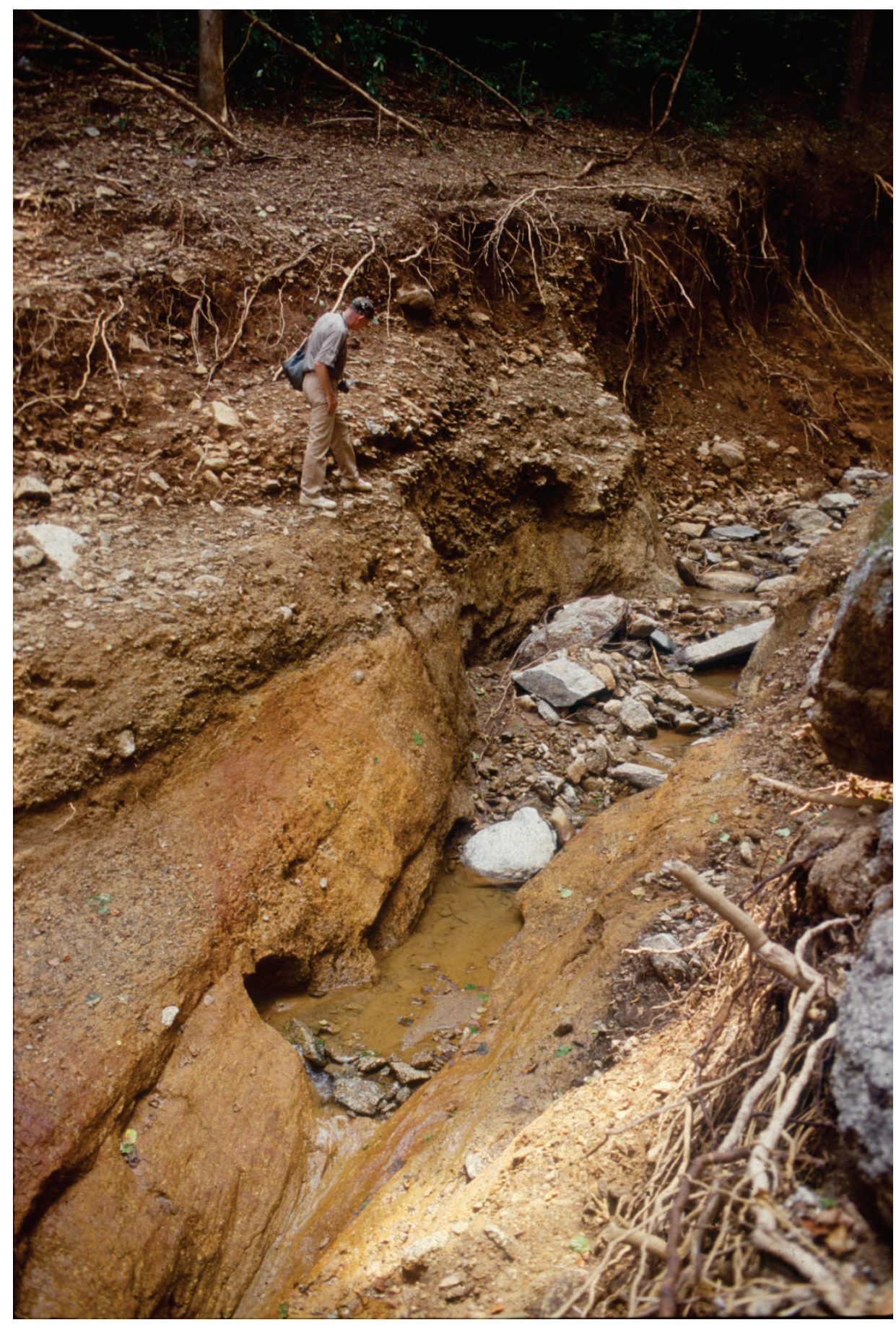

Figure 6. Scour from June 27, 1995, debris flow in Madison County, Va., revealing older debris-flow deposits.

Later on the evening of June 27, between 9 and 11 p.m., a similar storm developed over the Moormans River area in Shenandoah National Park in western Albemarle County. At least 29 mm of rain fell during this approximate 2-hour period. No hikers were within the Park during the event, and the rain gage was near the apparent periphery of the storm; therefore, there were no direct witnesses to the storm or the ground failures. Using infrared aerial photography, a map of the area was constructed showing 61 debris-slide scars (Morgan and Wieczorek, 1996). The area is entirely underlain by 
metabasalt and clay-rich saprolite. Massive debris slides developed within weathered metabasalt and were characterized by deep scarps at the head of the failures, slopes between 19 and 26 degrees, and broad, poorly defined channels, usually less than $300 \mathrm{~m}$ long. In addition to debris slides, there were a number of smaller slumps and soil slips. The debris slides converged into the Moormans River to create a powerful debris torrent that scoured the valley walls, creating major scarps along the thalweg and depositing a delta of debris into the downstream Charlottesville Reservoir (Morgan and Wieczorek, 1996). The rainfall in the Moormans River area exceeded $279 \mathrm{~mm}$ (Morgan and Wieczorek, 1996) but may have been as great as $635 \mathrm{~mm}$ (Eaton, 1999).

The June 1995 storm had a significant impact on a third region in the Blue Ridge. Located approximately $120 \mathrm{~km}$ southwest of the Rapidan Basin, the site is near Buena Vista in eastern Rockbridge County. Although no direct rainfall measurements were available from the field area, the National Oceanic and Atmospheric Administration (NOAA) estimates that approximately $213 \mathrm{~mm}$ of rain fell on June 27. The nearby Maury River (basin area $1,676 \mathrm{~km}^{2}$ ) reached a flood stage and peak flow of $19.5 \mathrm{ft}$ and $37,500 \mathrm{ft}^{3} / \mathrm{s}$, respectively, and was the third largest flood of record since the installation of the USGS gaging station in 1936. The deluge triggered 53 individual failures, primarily debris slides and flows, within a $\sim 50-\mathrm{km}^{2}$ area in steep, rugged topography. The majority of the debris flows initiated in zero- and first-order drainages on slopes exceeding 28 degrees. The basins are underlain by conglomerate, phyllite, metasiltstone, and quartzite of the Chilhowee Group; specifically, the Antietam quartzite was the dominant rock within most of the failure zones. Sas and Eaton (2008) found evidence that possible mechanisms of the slope failures include (1) elevated rates of hydraulic recharge in fracture zones, (2) structural controls dominated by the intersections of joint and bedding planes, and (3) significant contrasts in the hydraulic conductivities between rock and regolith materials, thereby increasing pore pressures and subsequent failures. The research also found that the denudation values of two of the impacted basins were exceptionally high and were probably the result of a combination of factors, including high-storm and antecedent rainfalls; steep topography; numerous, deep-seated wedge failures; and an abundance of regolith along the debris-flow chutes.

\section{West Virginia}

On June 17 and 18, 1949, an intense convectional storm produced over $400 \mathrm{~mm}$ of rainfall in a 24-hour period in the North Fork Mountain area in eastern West Virginia (Hack and Goodlett, 1960). This storm resulted in floods on the South and North Branches of the Potomac River and triggered debris flows in soils derived from sandstone on the steep upper slopes of North Fork Mountain (Cenderelli and Kite, 1998). At least 8 persons were killed and about 2,400 residents were driven from their homes (Clark, 1987b). The runoff produced dozens of debris slides on the upper mountain slopes, enlarged most of the channels, reworked debris on the bottom lands of many large valleys, and, in places, removed the forest cover on the entire valley floor. The largest of the debris flows on North Fork Mountain had its head 160 feet below the ridge crest and traveled approximately $2.5 \mathrm{~km}$. Its width at the head of the debris flow was $12 \mathrm{~m}$ and gradually increased to $43 \mathrm{~m}$ at its base (Stringfield and Smith, 1956). According to Cenderelli and Kite (1998), the largest debris flow had a combined length (failure zone, transport zone, and deposition zone included) of $2,600 \mathrm{~m}$ with a volume total of $17,300 \mathrm{~m}^{3}$ and a volume of deposited sediment of $12,000 \mathrm{~m}^{3}$.

Hurricane Camille, in addition to the devastating storm that impacted Nelson County, Va., also had a separate but major impact on August 19 and 20, 1969, in the Spring Creek drainage basin of Greenbrier County in eastern West Virginia (Radbruch-Hall and others, 1982). Debris flows and related flood damage were concentrated in an elongate pattern directly under the area of most intense rainfall, in an area of approximately $58 \mathrm{~km}^{2}$, although the total area affected was approximately $94.2 \mathrm{~km}^{2}$ 
(Schneider, 1973). Debris flows were triggered on slopes that averaged 35 degrees, with a minimum slope of 19 degrees on clear land and 17 degrees in timberland (Schneider, 1973). As many as 1,584 debris flows and debris slides occurred in this area. According to Schneider, the volume of material removed by an individual slide ranges from $0.3 \mathrm{~m}^{3}$ to approximately $24,366 \mathrm{~m}^{3}$. The total volume of material removed was $147,684 \mathrm{~m}^{3}$. The range in maximum slide scar-head width is less than 3.7 to 160 $\mathrm{m}$. The area of land disturbed at an individual site and the volume of regolith removed range from 1.9 $\mathrm{m}^{2}$ disturbed and $1.9 \mathrm{~m}^{3}$ removed, to $6,029 \mathrm{~m}^{2}$ and $24,369 \mathrm{~m}^{3}$ distributed and removed, respectively.

Rainfall from Hurricane Juan, November 3 through November 5, 1985, triggered numerous landslides, including debris slides and debris flows in the area of North Fork Mountain in eastern West Virginia and western Virginia (Jacobson, 1993). In this area of Pendleton County, W.V., and Highland County, Va., rainfall varied from less than 170 to more than $240 \mathrm{~mm}$, resulting in more than 3,000 ground failures of all types. Most failures occurred at the northeast end of the study area where 48-hour rainfall totals were in excess of $200 \mathrm{~mm}$. Most of the landslides triggered by the storm were classified as debris slumps, debris slides, earth slides, and debris flows, according to accepted landslide terminology (Varnes, 1978). Most failures were shallow, planar slides with depths rarely exceeding $2 \mathrm{~m}$, and showed minor rotational movement. A smaller number of failures occurred in colluvial aprons at the base of slopes and were presumably triggered by lateral stream erosion of the slope toes. Eight large debris flows on North Fork Mountain began as sliding masses of sandstone residuum and colluvium. The masses moved down steep slopes and flowed as much as $2 \mathrm{~km}$, with varying amounts of erosion and deposition. Ninety-five percent of the earth failures triggered by the November storm were slides, slide flows, slumps, or slump flows. The remaining 5 percent can be classified as debris flows and debris slides transitional to debris flows. According to Cenderelli and Kite (1998), the largest landslide was a debris flow at Twin Run with a total deposition of eroded sediment of $13,900 \mathrm{~m}^{3}$ with a total length of $2,848 \mathrm{~m}$.

\section{Kentucky}

A thunderstorm on July 4 and 5, 1939, released $508 \mathrm{~mm}$ of rain that triggered four debris flows and many other earth failures in Wolfe and Breathitt Counties, eastern Kentucky. Flooding and slope failures resulted in 78 deaths (Schrader, 1945). Debris slides and debris flows resulted from another storm on June 21, 1956, according to Clark (1987b).

\section{Pennsylvania}

During the night and morning of July $18-19,1942$, an astonishing $782 \mathrm{~mm}$ of rain and hail fell in at least one locality during a thunderstorm complex in just 4.5 hours. Other localities lacked the intensity but received approximately $889 \mathrm{~mm}$ during a 12-hour period (Scott, 1972; Eisenlohr, 1952). The storm was centered in Elk, McKean, Potter, and Cameron Counties of Pennsylvania, and triggered numerous landslides, including debris slides and flows, although the numbers of were not recorded. One of the largest debris flows moved downslope for more than $1.6 \mathrm{~km}$ and was nearly $0.4 \mathrm{~km}$ wide at its base where it entered Kettle Creek in Clinton County (Eisenlohr, 1952).

Hurricane Diane released at least $245 \mathrm{~mm}$ of rain in northeastern Pennsylvania on August 17-19, 1955. Four debris flows were triggered on the face of the Pocono Escarpment in the headwaters area of Brodhead Creek (Scott, 1972). Hack and Goodlett (1960) visited the area and measured one slide chute at $300 \mathrm{~m}$ long and $15 \mathrm{~m}$ wide.

Within the Johnstown area of western Pennsylvania, a thunderstorm resulted in $300 \mathrm{~mm}$ of rain that fell during a 9-hour period on July 19-20, 1977 (Brua, 1978). Several hundred debris slides, debris flows, slumps, earthflows, and combinations of the various types of landslides took place. The largest of 
the debris flows were triggered on 40-degree slopes with head scarps as wide as $25 \mathrm{~m}$ and as deep as 4 m (Pomeroy, 1980).

On August 14, 1980, a thunderstorm triggered slope movements of debris slides and debris flows at East Brady, along the Allegheny River in northern Pennsylvania (Pomeroy, 1984). The highest density of earth failures was on an east-facing slope opposite East Brady with about 85 failures per square kilometer (Pomeroy, 1984). On the same slope 1 to $3 \mathrm{~km}$ east of East Brady, a smaller number (56 per square kilometer) was recorded. The head of one debris flow was $6 \mathrm{~m}$ wide and 2.5 to $3.0 \mathrm{~m}$ deep, and the flow was $135 \mathrm{~m}$ long. A minimum of $1,500 \mathrm{~m}^{3}$ of colluvium was flushed out of the channel and into the Allegheny River (Pomeroy, 1984).

\section{Summary of Observations on Debris Flows}

We summarize data on the triggering, occurrence, and effects of debris flows in the central and southern Appalachians. This account is based primarily on the well-documented occurrences noted in table 1 and field studies published in Morgan and Wieczorek (1996), Morgan and others (1999a, b), Wieczorek and others (2000), Eaton and others (2003a, b), and Wooten and others (2008a, b).

The principal conditions that must prevail to trigger debris flows are excessive rainfall, elevated terrain with steep slopes, and a susceptible supply of material.

Rainfall totals for nineteen debris-flow occurrences are given in table 1 and range widely from $115 \mathrm{~mm}$ to as much as $800 \mathrm{~mm}$ over periods of 14 days to 1 hour. The rate of rainfall appears to be more critical than the total rainfall (fig. 7). This figure indicates that critical rainfall conditions in the Blue Ridge of central Virginia range from about $20 \mathrm{~mm} / \mathrm{hr}$ for a duration of 24 hours to up to $180 \mathrm{~mm} / \mathrm{hr}$ for a duration of about 1 hour. Unfortunately, for most of the best described events in the Appalachian region, rainfall data are scarce. Many events took place in isolated regions with few inhabitants, and most rain gages have a maximum capacity of 12 inches. The Nelson County storm occurred in a rural area of small farms, but the great majority of rain gages overflowed and yielded only minimum values for rainfall. Contours of rainfall are available for only two of the events that occurred within Nelson and Madison Counties (shown in Morgan and others, 1999a, b). Actual rainfall patterns are more complex than the apparent bull's-eye of the contoured data. The actual trace of the Madison storm determined by Smith and others (1996) and shown plotted on the Madison storm and debris-flow map (Morgan and others, 1999a) passed over the area in a broad " $U$ " shape so that the central area was inundated twice in a short period, giving a total of $770 \mathrm{~mm}$ in that location. Figure 8 shows the rate of rainfall and the time of directly witnessed debris-flow impacts at a given location for the Madison storm. These debris flows were triggered during periods of rapid rainfall-rate increases rather than just being the result of the total rainfall. Finally, we do not know what role that antecedent precipitation plays in setting the conditions for debris-flow triggering during intense rainfall. In the Madison area, antecedent rainfall 3 days before the debris-flow event ranged from 60 to $100 \mathrm{~mm}$, thoroughly soaking the colluvium. 
Intensity - Duration Threshold for central Blue Ridge, Virginia

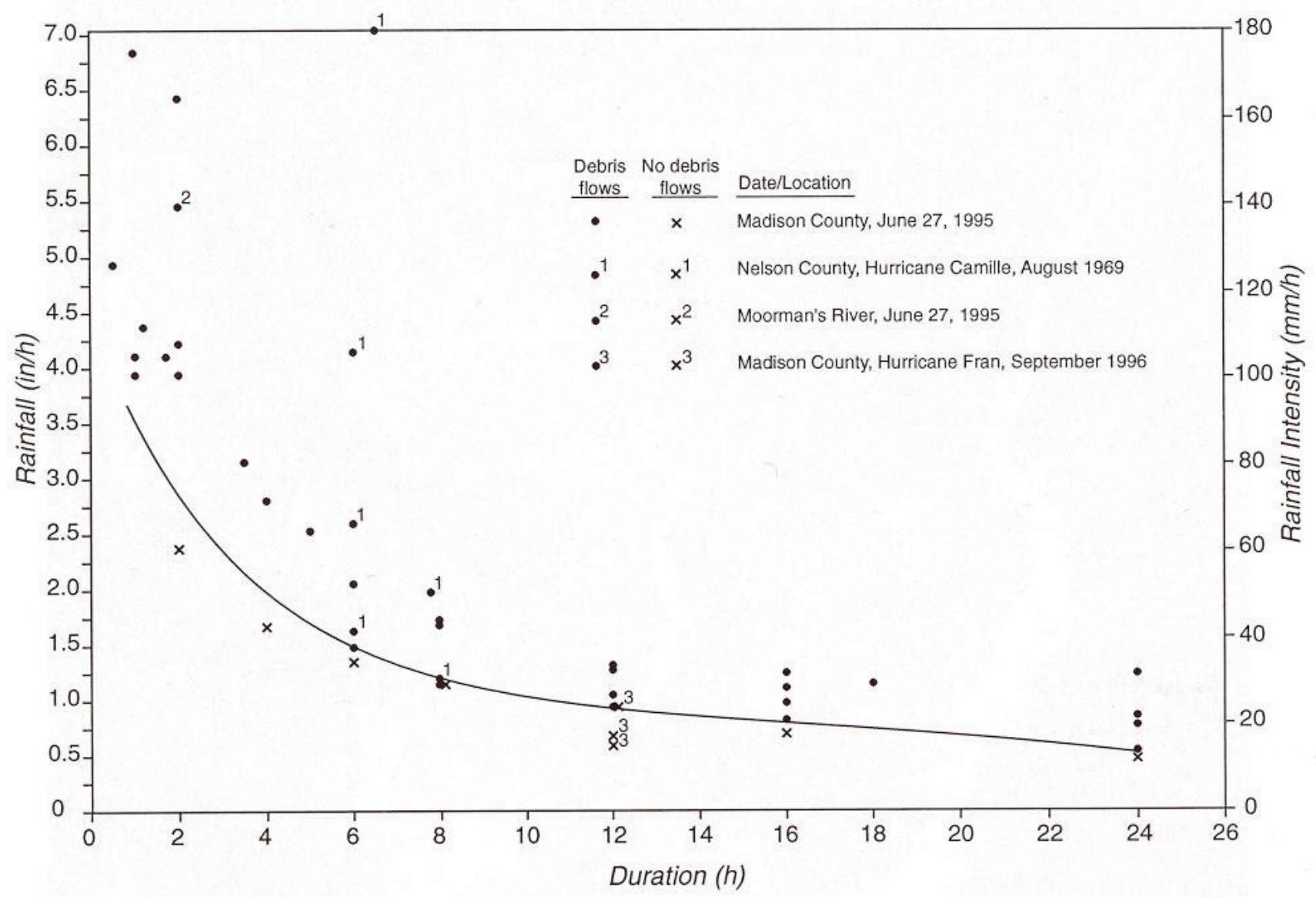

Figure 7. Rainfall intensity and duration for storms in the Blue Ridge of central Virginia. The line depicts a predicted threshold that represents minimum values necessary for triggering debris flows (Wieczorek and others, 2000). 


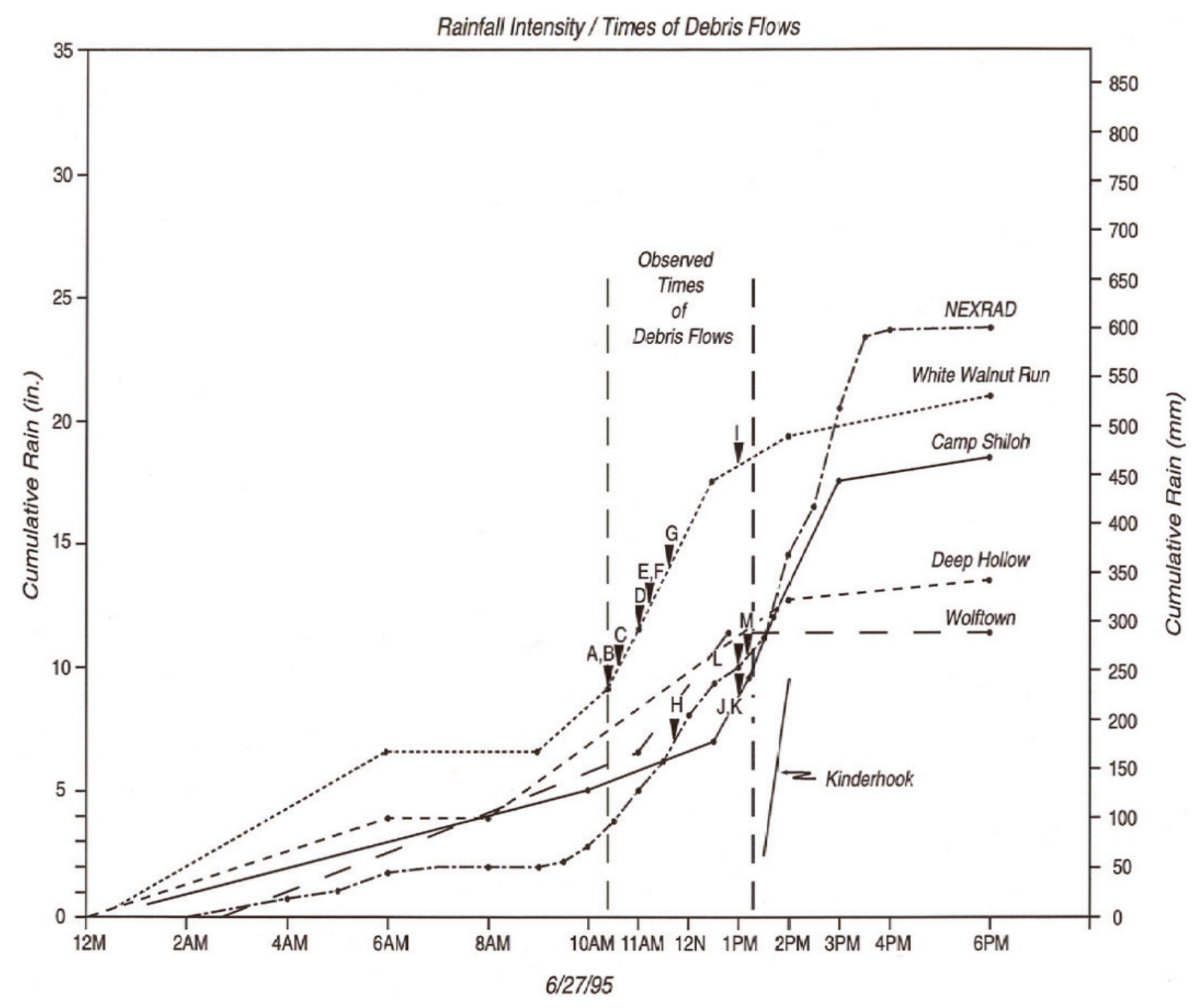

Figure 8. Rainfall and a few observed times of debris flows (shown as letters A-M) during the June 27, 1995, storm in Madison County, Va. (Wieczorek and others, 2000).

Steep slopes appear to be a critical condition for debris-flow occurrence. Clark's 1987 map depicted in figure 1 clearly shows the relationship of debris flows to the mountains of the central and southern Appalachians. Slope measurements, where taken, confirm a steep topography, with debris flows found more frequently on slopes greater than 20 degrees and averaging about 30 degrees.

A susceptible supply of material available for debris-flow occurrence is critical, but the characteristics of that supply will vary widely, because of both the underlying bedrock of the region and its history of weathering and erosion. Areas underlain by shales and intercalated thinly bedded shales and sandstones will respond more readily to debris-flow triggering (Jacobson, 1993). For example, two locations underlain by sedimentary rocks, specifically the Allegheny River in Pennsylvania and Pendleton County, W. Va., experienced numerous slope failures from a storm that dropped $145 \mathrm{~mm}$ and $350 \mathrm{~mm}$, respectively, over several days. In contrast, storms having similar rainfall intensities have not affected the metagranitic rocks of the Virginia Blue Ridge. Highly jointed quartzites and sandstones 
proved to be susceptible lithologies in a debris-flow event near Buena Vista, Va., in 1995 (Sas and Eaton, 2008). In the Blue Ridge of central Virginia, we believe that periglacial conditions resulted in the widespread cover of loosely consolidated mountain top debris above an elevation of about $600 \mathrm{~m}$ (Clark, 1987a). This material is highly susceptible to mobilization during heavy rainfall.

The suggestion has been made that colluvium collects in coves along ridge crests until metastability is attained during excessive rainfall (see Hack and Goodlett, 1960; Kochel, 1987). We carefully tested this hypothesis in the Madison County area and determined that approximately twothirds of the triggering sites were in concave or cove sites. Data from debris-flow initiation sites in North Carolina also show that about two-thirds of the sites were in concave slopes. Inspection of aerial photography in the Nelson County area revealed that many triggering sites were not in coves but along ridge crests and occasionally on convex surfaces. Triggering sites in the Moormans River area frequently occurred on convex slopes. Residual soil development and colluvial accumulation from weathered and saprolitized bedrock are slow processes. Carbon samples from saprolitized material were invariably radiometrically "dead," indicating an age greater than 50,000 ybp. Onsite recurrence intervals appear to be much shorter, in the range of 3,000 to 5,000 years (Eaton and others, 2003a). On the basis of these data, we believe that debris-flow occurrences in the Blue Ridge are not a steady-state phenomena based on continued accumulation of colluvium and residual soils. Instead, debris-flow occurrences are the result of historical or contingency processes during which periglacial debris and surficial materials are progressively mined out of the terrain more rapidly than they can accumulate.

Ground failure at the source is almost always a debris slide characterized by a relatively planar detachment surface. Upslope migration of the failure sites was not observed in the Madison area. The debris slide evolved into a flow within 10 to $20 \mathrm{~m}$ downslope as evidenced by scouring of the detachment surface and development of lateral levees. Once triggered and moving, the debris flow does move directly downslope into the drainage network and loosely follows the stream channel. Long transport and substantial sediment discharge of a debris flow are dependent on entrainment of material downslope, indicating that soil saturation and the presence or absence of a perched water table along the path are critical factors. In our study of a tributary of Kinsey Run in Madison County (Wieczorek and others, 2000), we found that more than 90 percent of the sediment discharge was contributed by entrained material along the path of the flow. Super elevation of the flow above the channel (Johnson 1970, 1984) was often observed along this drainage with measured velocities of $24 \mathrm{~m} / \mathrm{s}$ near the head of the scarp and slowing to $8 \mathrm{~m} / \mathrm{s}$ near the depositional fan (Wieczorek, and others, 2000). The upper and steeper chutes of the debris-flow path are marked by extensive scour, lateral levees, and plunge pools; the lower gentle slopes of the path are the sites of deposition. However, multiple debris-flow surges along the same channel coming from different headward tributaries can create a complex geometry of deposition followed by scour and then later by deposition over the earlier flow sites.

Deposition of debris-flow discharged material in the Madison and Nelson Counties areas is on prominent fans bordering the larger streams and rivers in the area. These fans are irregular in map view and confined to the valley walls and have been built up by successive late Pleistocene and recent debrisflow and fluvial deposition (Kochel and Johnson, 1984). Field studies in Macon County, N.C., identified preexisting debris deposits at all of the 62 relatively recent debris-flow sites, an indication that earlier, and, in many cases, multiple debris-flow events had occurred (Wooten and others, 2008a).

In the Moormans River area, and possibly along Davis Creek in Nelson County, debris slides and small debris flows converged into a river in a full-flood state, creating a hypoconcentrate flow or debris torrent (Costa, 1988). In the Moormans River, this torrent moved with great erosive force, cutting away banks and, in a series of successive surges, carrying debris downsteam and filling nearly one-half 
of the Charlottesville Reservoir. Davis Creek in Nelson County was also probably the site of a debris torrent and was the site of the greatest loss of life for any of these events, with 50 casualties in that area.

\section{Future Research}

Figure 7 is an algorithm depicting critical rainfall rates and duration necessary to trigger debris flows in the Blue Ridge of central Virginia. Similar algorithms have been developed for other areas and are shown in figure 8 (Wieczorek and others, 2000). This figure documents that the weather conditions necessary to trigger flows in the Blue Ridge are more extreme than those in other areas that have been studied. We believe that this is mainly a function of sediment supply. The Virginia Blue Ridge is a mature landscape, with a protracted erosion history, and is underlain by highly competent metaigneous rocks and metasedimentary rocks with a relatively thin carapace of soils, saprolite, and mountain top colluviums (Clark, 1987a). Apparently, these characteristics combine in such a way that a high level of activation energy is required to initiate debris flows in the Blue Ridge in central Virginia. We have no reliable information necessary to develop a similar algorithm for other geologic provinces in the central and southern Appalachians. Areas underlain by sandstones and shales in western Virginia, West Virginia, and much of Pennsylvania could respond with very different thresholds for ground-failure triggering.

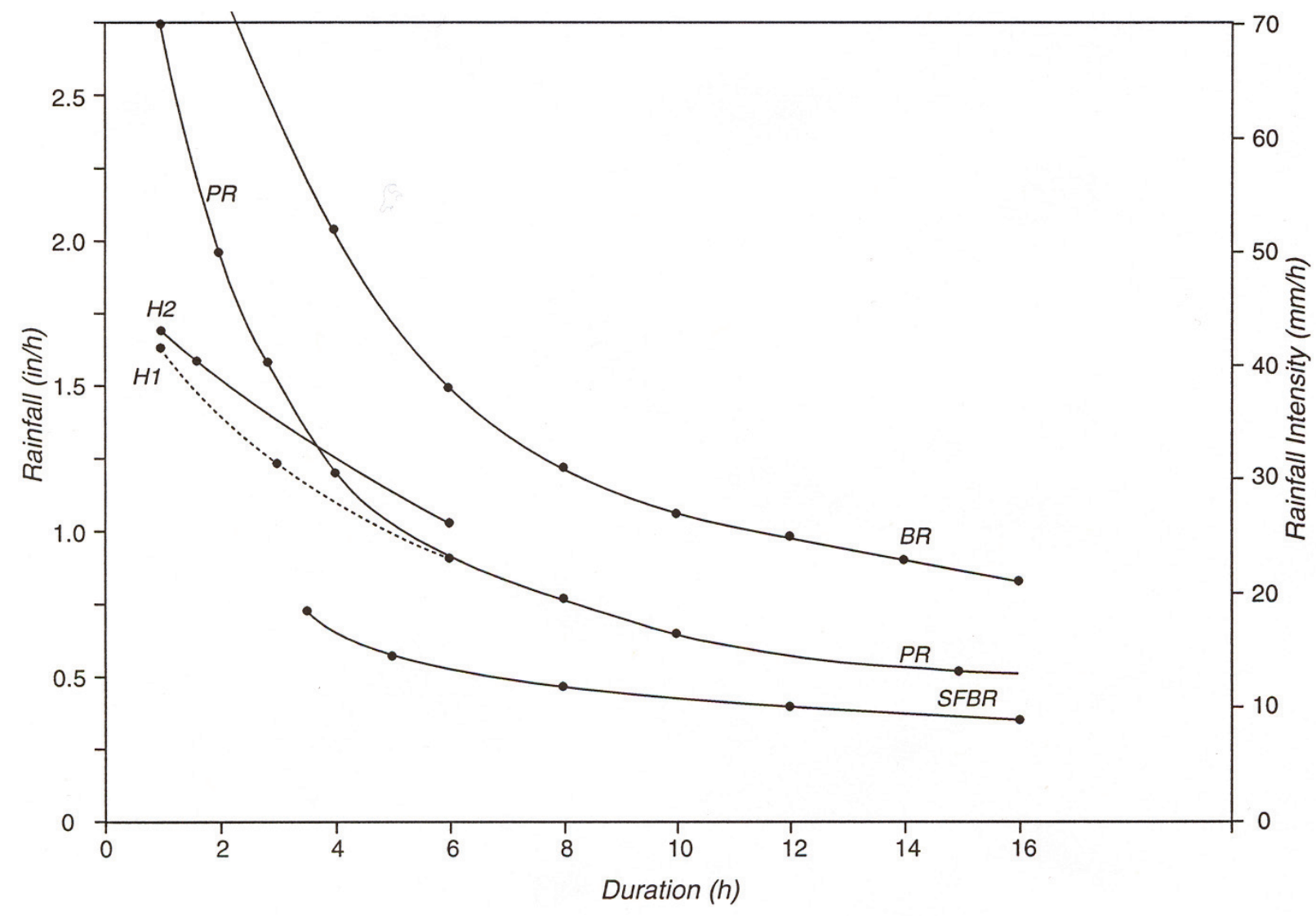

Figure 9. Rainfall intensity-duration for debris-flow thresholds for Blue Ridge (BR); Hawaii (H1, H2) (Wilson and others, 1992); San Francisco Bay Region (SFBR) (Cannon and Ellen, 1985); and Puerto Rico (PR) (Jibson, 1989; Larsen and Simon, 1993). 
Factors leading to the saturation by rainfall of surficial materials leading to the loss of cohesion and internal friction are not well understood. These include the role of antecedent rainfall in preparing the ground before a major rainfall, the nature of the regolith, especially the clay content and permeability, and the role of bedrock, including the extent of jointing and other planar characteristics, such as bedding, cleavage, and foliations.

Sedimentological experiments and computer modeling have been used to develop predictive tools. These have been increasingly applied over the past decade, and an extensive literature has been published. These include experimental studies by Iverson and others (1994) and modeling studies applied to the Nelson County storm (Morrissey and others, 2001, 2008). An extensive survey of landslide hazards in western North Carolina is being undertaken, and computer modeling is a standard application in this effort to delineate areas of potential hazard (see Wooten and others, 2008b). Increased sophistication of these modeling programs, coupled with new remotely sensed mapping of surficial features, including side-looking radar and Light Detection and Ranging (LIDAR), offers a promising avenue for investigation of landslides in remote locations and broad areas of the Appalachians.

Recurrence intervals for debris-flow activity at a given site are almost completely unknown. Using the historical record, large areas, such as Virginia, appear to have a recurrence interval of about 15 years, whereas, for western North Carolina, the interval appears to be much shorter, perhaps as little as 3 years. Witt (2005) reported that the recurrence of debris-flow events averages 16 years for the French Broad watershed in North Carolina (over 7,000 $\left.\mathrm{km}^{2}\right)$; for small watersheds $\left(<10 \mathrm{~km}^{2}\right)$, Wooten and others (2008a) reported recurrence could be on the order of decades. A more accurate determination of the recurrence interval for a given site can be obtained through investigation of prehistoric debris flows with ages determined by $\mathrm{C}^{14}$ (Kochel, 1987), and Eaton and coworkers (Eaton and McGeehin, 1997; Eaton and others, 2003a, b) have undertaken an exhaustive study of prehistoric debris flows dated by the age window for $\mathrm{C}^{14}$. For the Madison area, Eaton concluded that the recurrence interval was approximately 3,000 years. A similar conclusion was reached, on a much shorter time interval, by Kochel (1987) working on Davis Creek in the Nelson County area. Recurrence intervals, of course, are a function of scale, with the interval decreasing as larger areas are considered. Research is needed to determine the recurrence intervals for debris flows in the Ridge and Valley Province or in the highlands of North Carolina.

Warning the public of potential or impending debris-flow hazards will require a concerted effort by local, State, and Federal Governments. A network of rain gages that records rainfall in real time is available in parts of the southern and central Appalachian Mountains and could become more widely developed in the region. To be effective as a hazard-warning system, the rain-gage network should be integrated with radar precipitation data, hillslope monitoring information, and radio, television, and Internet communications for State Emergency Response Centers and public and emergency managers in areas of concern. If a set of algorithms similar to those in figure 7 can be developed for the several geologic provinces of the Appalachians, the rainfall-time thresholds indicated by these algorithms can provide the basis for hazard alerts. Long-range mitigation of debris-flow hazards can be improved by careful placement and strengthening of roads (Collins, 2008) and bridges and by the selection of sites for new construction that are away from areas most susceptible to landslide failure and subsequent inundation by debris flows.

\section{References Cited}

Bogucki, D.J., 1976, Debris slides in the Mt. Le Conte area, Great Smoky Mountains National Park, U.S.A.: Geografiska Annaler, v. 58, no. 3, p. 179-191. 
Brua, S. A., 1978, Floods of July 19-20, 1977 in the Johnstown area, western Pennsylvania: U.S. Geological Survey Open-File Report 78-963, 62 p.

Campbell, R.H., 1975, Soil slips, debris flows, and rainstorms in the Santa Monica Mountains and vicinity, southern California: U.S. Geological Survey Professional Paper 851, 51 p.

Cannon, S.H., and Ellen, S.D., 1985, Rainfall conditions for abundant debris avalanches in the San Francisco Bay region, California: California Geology, v. 38, no. 12, p. 267-272.

Cenderelli, D.A., and Kite, J.S., 1998, Geomorphic effects of large debris flows on channel morphology at North Fork Mountain, eastern West Virginia, USA: Earth Surface Processes and Landforms, v. 23, p. $1-19$.

Clark, M.G., 1987a, Debris slide and debris-flow historical events in the Appalachians south of the glacial border, in Costa, J.E., and Wieczorek, G.F., eds., Debris flows/avalanches-Process, recognition and mitigation: Geological Society of America, Reviews in Engineering Geology, v. 7, p. $125-138$.

Clark, M.G., 1987b, Storm-related geomorphic effects of the 17-18 June, 1949 rainfall event in the ridge and valley providence of West Virginia, in Kite, J.S., ed., Research on the Late Cenozoic of the Potomac Highlands, Southeastern Friends of the Pleistocene, Volume 1: West Virginia Geological and Economic Survey Report OF8802, p. 56-62.

Collins, T.K., 2008, Debris flows caused by failure of fill slopes-Early detection, warning and loss prevention: Landslides, v. 5, no. 1, p. 107-119.

Costa, J.E., 1988, Rheologic, geomorphic, and sedimentologic differentiation of water floods, hyperconcentrated flows, and debris flows, in Baker, V.R., Kochel, R.C., and Patton, P.C., eds.: New York, John Wiley, Flood Geomorphology, p. 113-122.

Delano, H.L., and Potter, N., Jr., 1997, The Carlisle deluge, 1779 revisited: Cumberland Country History, v. 14, no. 1, p. 68-70.

Eaton, L.S., 1999, Debris flows and landscape evolution in the upper Rapidan basin Blue Ridge Mountains, central Virginia: Charlottesville, Va., Ph.D. thesis, 154 p.

Eaton, L.S., and McGeehin, J.P., 1997, Frequency of debris flows and their role in the long term landscape evolution in the central Blue Ridge (abs.): Geological Society of America Abstracts with Programs, v. 219, no. 6, p. 410.

Eaton, L.S., Morgan, B.A., Kochel, R.C., and Howard, A.D., 2003a, Quaternary deposits and landscape evolution of the central Blue Ridge of Virginia: Geomorphology, v. 56, p. 139-154.

Eaton, L.S., Morgan, B.A., Kochel, R.C., and Howard, A.D., 2003b, Role of debris flows in long-term landscape denudation in the central Appalachians of Virginia: Geological Society of America, Geology, v. 31, no. 4, p. 339-342.

Eisenlohr, W. S., Jr., 1952, Floods of July 18, 1942 in north-central Pennsylvania: U.S. Geological Survey Water-Supply Paper 1134-B, 100 p.

Hack, J.T., and Goodlett, J.C., 1960, Geomorphology and forest ecology of a mountain region in the Central Appalachians: U.S. Geological Survey Professional Paper 347, 66 p.

Iverson, R.M., LaHusen, R.G., Major, J.J., and Zimmerman, C.L., 1994, Debris flow against obstacles and bends - dynamics and deposits: EOS, Transactions of the American Geophysical Union, v. 75, no. 44, p. 274.

Jacobson, R.B., ed., 1993, Geomorphic studies of the storm and flood of November 3-5, 1985, in the Upper Potomac and Cheat River Basins in West Virginia and Virginia: U.S. Geological Survey Bulletin 1981, 187 p. 
Jibson, R.W., 1989, Debris flows in southern Puerto Rico, in Schultz, A.P. and Jibson, R.W., eds., Landslide processes of the Eastern United States and Puerto Rico: Geological Society of America Special Paper 236, p. 29-55.

Johnson, A.M., 1970, Physical processes in geology: San Francisco, Calif., Freeman, Cooper \& Company, $577 \mathrm{p}$.

Johnson, A.M., 1984, Debris flow, in Brunsden, Denys, and Prior, D.B., eds., Slope instability: New York, John Wiley \& Sons, p. 257-361.

Koch, C.A., 1974, Debris slides and related flood effects in the 4-5 August 1938 Webb Mountain cloudburst - some past and present environmental geomorphic implications: Knoxville, University of Tennessee, M.S. thesis, $112 \mathrm{p}$.

Kochel, R.C., 1987, Holocene debris flows in central Virginia, in Costa, J.E., and Wieczorek, G.F., eds., Debris flows/avalanches - process, recognition and mitigation: Geological Society of America, Reviews in Engineering Geology, v. 7, p. 139-155.

Kochel, R.C., and Johnson, R.A., 1984, Geomorphology and sedimentology of humid-temperate alluvial fans, central Virginia, in Koster, E.H., and Steele, R.J., eds., Sedimentology of gravels and conglomerates: Canadian Society Petroleum Geologists Memoirs 10, p. 109-122.

Larsen, M.C., and Simon, Andrew, 1993, A rainfall intensity-duration threshold for landslides in a humid-tropical environment, Puerto Rico: Geolgrafiska Annler, v. 75A, nos. 1-2, p. 13-23.

Latham, R.S., Wooten, R.M., and Reid, J.C., 2005, Preliminary findings on the September 16, 2004 debris flow at Peeks Creek, Macon County, North Carolina, in Highway Geology Symposium, 56th, Wilmington, N.C., May 4-6, 2005: Proceedings, p. 277-290.

Latham, R.S., Wooten, R.M., Witt, A.C., and Brame, S., 2006, Investigation of the Peeks Creek debris flow of September 2004, Macon County, North Carolina: Clemson University, 14th Annual David S. Snipes/Clemson Hydrogeology Symposium Field Trip Guidebook.

Latham, R.S.; and others, 2007, Investigation of the Peeks Creek debris flow of September 2004 and its relationship to landslide hazard mapping in Macon County, North Carolina: 2007 Southeast Friends of the Pleistocene Field Trip Guidebook, 35 p.

Morgan, B.A., and Wieczorek, G.F., 1996, Debris flows and landslides resulting from the June 27, 1995, storm in the North Fork Moormans River, Shenandoah National Park, Virginia: U.S. Geological Survey Open-File Report 96-503, 10 p., 1 plate, scale 1:24,000.

Morgan, B.A., Wieczorek, G.F., Campbell, R.H., and Gori, P.H., 1997, Debris-flow hazards in areas affected by the June 27, 1995, storm in Madison County, Virginia: U.S. Geological Survey Open-File Report 97-438, 15 p., 2 tables, 2 plates, also available at http://pubs.usgs.gov/of/1997/438/.

Morgan, B.A., Iovine, G., Chirico, P., and Wieczorek, G.F., 1999, Inventory of debris flows and floods in the Lovingston and Horseshoe Mountain, VA, 7.5' quadrangles, from the August 19/20, 1969, storm in Nelson County, Virginia: U.S. Geological Survey Open-File Report 99-518, 1 plate, scale 1:24,000, 9 p., also available at http://pubs.usgs.gov/of/1999/ofr-99-0518/.

Morgan, B.A., Wieczorek, G.F., and Campbell, R.H., 1999a, Map of rainfall, debris flows, and flood effects of the June 27, 1995, storm in Madison County, Virginia: U.S. Geological Survey Geologic Investigation Series Map I-2623-A, 1 plate, scale 1:24,000.

Morgan, B.A., Wieczorek, G.F., and Campbell, R.H., 1999b, Historical and potential debris-flow hazard map of area affected by the June 27, 1995, storm in Madison County, Virginia: U.S. Geological Survey Geologic Investigation Series Map I-2623-B, 1 plate, scale 1:24,000.

Morrissey, M.M., Wieczorek, G.F., and Morgan, B.A., 2001, Regional application of a transient hazard model for predicting initiation of debris flows in Madison County, Virginia: U.S. Geological Survey Open-File Report 01-481, 7 p., 6 figs., CD-ROM. 
Morrissey, M.M., Wieczorek, G.F., and Morgan, B.A., 2008, A comparative analysis of simulated and observed landslide locations triggered by Hurricane Camille in Nelson County, Virginia: New York, John Wiley \& Sons: Hydrological Processes, v. 22, no. 4, p. 524-531, available at http://www3.interscience.wiley.com/cgi-bin/fulltext/116332429/PDFSTART.

Neary, D.G., and Swift, L.W., Jr., 1987, Rainfall thresholds for triggering a debris avalanching in the southern Appalachian Mountains: Geological Society of America, Reviews in the Engineering Geology, v. 7, p. 81-92, available at http://cwt33.ecology.uga.edu/publications/623.pdf.

Pomeroy, J.S., 1980, Storm-induced debris avalanching and related phenomena in the Johnstown area, Pennsylvania, with references to other studies in the Appalachians: U.S. Geological Survey Professional Paper 1191, 24 p.

Pomeroy, J.S., 1984, Storm-induced slope movements at East Brady, northwestern Pennsylvania: U.S. Geological Survey Bulletin 1618, 16 p.

Pomeroy, J.S., 1991, Map showing late 1977 debris avalanches southwest of Asheville, western North Carolina: U.S. Geological Survey Open-File Report 91-334, 25 p., scale 1:24,000.

Potter, N., Jr., and Delano, H.L., 1997, The Carlisle (PA) deluge revisited; a debris flow in 1779: Geological Society of America Abstracts with Programs, v. 29, no. 6, p. 411, available at http://www.geo.wvu.edu/ kite/PotterAndDelano1997.html.

Radbruch-Hall, D.H., and others, 1982, Landslide overview map of the conterminous United States: U.S. Geological Survey Professional Paper 1183, 25 p.

Sas, R.J., and Eaton, L.S., 2008, Quartzite terrains, geologic controls, and basin denudation by debris flows - their role in long-term landscape evolution in the central Appalachians: Landslides, v. 5, p. 97-106.

Schneider, R.H., 1973, Debris slides and related flood damage resulting from Hurricane Camille, 19-20 August, and subsequent storm, 5-6 September, 1969, in the Spring Creek drainage basin, Greenbrier County, West Virginia: Knoxville, University of Tennessee, Ph.D. thesis, 247 p.

Schrader, F.E., 1945, Notable local floods of 1939; Part 2. Flood of July 5, 1939 in eastern Kentucky: U.S. Geological Survey Water-Supply Paper 967-B, p. 41-59.

Scott, R.C., Jr., 1972, The geomorphic significance of debris avalanching in the Appalachian Blue Ridge Mountains: Athens, University of Georgia, Ph.D. thesis, 185 p.

Simpson, P.S., and Simpson, J.H., Jr., 1970, Torn land: Lynchburg, Va., J.P. Bell Co., 429 p.

Smith, J.A., Baeck, M.L., and Steiner, M., 1996, Catastrophic rainfall from an upslope thunderstorm in the central Appalachians-The Rapidan storm of June 27, 1995: Water Resources Research, v. 32, no. 10, p. 3099-3113.

Stringfield, V.T., and Smith, R.C., 1956, The relation of geology to drainage, floods, and landslides in the Petersburg area, West Virginia: West Virginia Geologic and Economic Survey Report of Investigations $13,19 \mathrm{p}$.

Tennessee Valley Authority (TVA), 1940, Floods of August 1940 in Tennessee River basin: Report 0243-675, $310 \mathrm{p}$.

Tennessee Valley Authority, 1964, Floods on the French Broad River, Davidson River, King Creek Nicholson Creek in the vicinity of Brevard, N.C.: Knoxville, Tenn., Tenessee Valley Authority Division of Water Control Planning Report No. 0-6373, 98 p.

U.S. Geological Survey, 1949, Floods of August 1940 in the southeastern States: U.S. Geological Survey Water-Supply Paper 1066.

Varnes, D.J., 1978, Slope movement types and processes, in Schuster, R.L., and Krizek, R.J., eds., Landslides analysis and control: Washington, D.C., Transportation Research Board, National Academy of Science, Special Report 176, p. 12-33. 
Wieczorek, G.F., Morgan, B.A., and Campbell, R.H., 2000, Debris-flow hazards in the Blue Ridge of central Virginia: Environmental \& Engineering Geoscience, v. 6, no. 1, p. 3-23.

Wieczorek, G.F., Mossa, G.S., and Morgan, B.A., 2004, Regional debris-flow distribution and preliminary risk assessment from severe-storm events in the Appalachian Blue Ridge province, USA: Landslides, v. 1, p. 53-59, available at http://www.springerlink.com/content/atmj2qx90yh24q0q/fulltext.html.

Wieczorek, G.F., and Leahy, P.P., 2008, Landslide hazard mitigation in North America: Environmental \& Engineering Geoscience, v. 14, no. 2, May 2008, p. 133-144.

Williams, G.P., and Guy, H.P., 1973, Erosional and depositional aspects of Hurricane Camille in Virginia, 1969: U.S. Geological Survey Professional Paper 804, 80 p.

Wilson, R.L., 1983, Debris flows resulting from the August 17, 1982, storm in southeast Tennessee and northwest Georgia: Geological Society of America Abstracts with Programs, v. 15, p. 112.

Wilson, R.C., Torikai, J.D., and Ellen, S.D., 1992, Development of rainfall warning thresholds for debris flows in the Honolulu district, Oahu: U.S.. Geological Survey Open-File Report 92-521, 45 p. Witt, A.C., 2005, A brief history of debris flow occurrence in the French Broad River watershed, western North Carolina: The North Carolina Geographer, v. 13, p. 58-82.

Witt, A.C., and others, 2007, Life, death and landslides-The August 13-14, 1940 storm event in Watauga County, North Carolina: Paper No. 26-3, SE Section, Geological Society of America, $56^{\text {th }}$ Annual Meeting.

Witt, A.C., and others, 2008, Migration to a geospatial database to improve data management in the N.C. Geological Survey’s Landslide Hazard Mapping Program: Geological Society of America Abstracts with Programs, v. 40, no. 6, p. 174.

Wooten, R.M., Carter, M.W., and Merschat, C.E., 2003, Geology of Gorges State Park, Transylvania County, North Carolina: North Carolina Geological Survey Section, Information Circular 31, 60 p.

Wooten, R.M., and others, 2008a, Geologic, geomorphic, and meteorological aspects of debris flows triggered by Hurricanes Frances and Ivan in the southern Appalachian Mountains of Macon County, North Carolina (southeastern USA): Landslides, v. 5, no. 1, p. 31-44.

Wooten, R.M., and others, 2008b, Slope movement hazard maps of Watauga County, North Carolina: N.C. Geological Survey Geologic Hazards Map Series 3, 3 sheets, scale 1:36,000. 